\title{
Discovery of novel antitumor nitric oxide-donating $\beta$ - elemene hybrids through inhibiting the PI3K/Akt pathway
}

Jichao Chen a, Tianyu Wang a, Shengtao Xu ${ }^{\text {a }}$, Pengfei Zhang a , Aijun Lin ${ }^{\text {a }}$, Liang Wu b,, Hequan Yao a, Weijia Xie ${ }^{\text {a }}$, Zheying Zhu ${ }^{\mathrm{c}, *}$, Jinyi Xu ${ }^{\mathrm{a}, *}$

a State Key Laboratory of Natural Medicines and Department of Medicinal Chemistry, China Pharmaceutical University, 24 Tong Jia Xiang, Nanjing 210009, P. R. China.

b Jiangsu Key Laboratory of Drug Screening, China Pharmaceutical University, 24 Tong Jia Xiang, Nanjing 210009, P. R. China.

${ }^{\mathrm{c}}$ Division of Molecular Therapeutics \& Formulation, School of Pharmacy, the University of Nottingham, University Park Campus, Nottingham NG7 2RD, U.K.

"Corresponding authors: E-Mail: wul2004@ hotmail.com (L. Wu);

E-Mail: Zheying.Zhu@ nottingham.ac.uk (Z. Zhu);

E-Mail: jinyixu@ china.com; Tel.: +86-25-8327-1299 (J. Xu).

\begin{abstract}
A series of novel furoxan-based NO-donating $\beta$-elemene hybrids were designed and synthesized to improve the anticancer efficacy of natural $\beta$-elemene. The bioassay results indicated that all of the target compounds exhibited significantly improved antiproliferative activities against three cancer cell lines (SGC-7901, HeLa and U87) compared to parent compound $\beta$-elemene. Interestingly, these compounds displayed excellent sensitivity to U87 cells with $\mathrm{IC}_{50}$ values ranging from 173 to $2 \mathrm{nM}$. Moreover, most compounds produced high levels of NO in vitro, and the antitumor activity of 11a in U87 cells was markedly attenuated by an NO scavenger (hemoglobin or carboxy-PTIO). Further mechanism studies revealed that 11a caused the G2 phase arrest of the cell cycle and induced apoptosis of U87 cells by preventing the activation of the PI3K/Akt pathway. Moreover, 11a significantly suppressed the tumor growth in H22 liver cancer xenograft mouse model with a tumor inhibitory ratio (TIR) of $64.8 \%$, which was superior to that of $\beta$-elemene (TIR, $49.6 \%$ ) at the same dose of $60 \mathrm{mg} / \mathrm{kg}$. Together, the remarkable biological profiles of these novel NO-donating $\beta$-elemene derivatives may make them promising candidates for the intervention of human cancers.
\end{abstract}

Key words: $\beta$-elemene; furoxan; antitumor activity; apoptosis; PI3K/Akt pathway 


\section{Introduction}

Over past centuries, natural products have played a key role in drug discovery and development. They provided the basis and inspiration for developing effective therapeutics for human diseases [1,2]. Review of natural products (NPs) over the 34 years from 1981 to 2014 revealed that approximately $51 \%$ of the developed therapeutic agents approved by the Food and Drug Administration were NPs, their derivatives, and synthetic mimetics related to NPs. Especially in the antitumor area, the percentage has risen to ca. 65\% [3].

$\beta$-Elemene (7, Scheme 1), a sesquiterpene compound isolated from the traditional Chinese medicinal herb Curcuma aromatica Salisb. [4], has been used as an anticancer drug in China for many years [5]. Numerous reports have demonstrated that $\beta$-elemene exhibited its antineoplastic activity in vivo against various human tumors such as glioblastoma [6], liver [7] and breast [8] cancers. It inhibited tumor cell growth via diverse mechanisms including induction of apoptosis, autophagy and cell cycle arrest, and inhibition of cell proliferation and migration [6-9]. No severe side effects were observed in the clinical studies, and on the contrary, patient immunity was improved during the therapy with $\beta$-elemene $[10,11]$. Despite these attractive anticancer properties, the moderate antitumor potency and poor bioavailability of $\beta$-elemene hampers its wide application in clinic. In particular, high concentrations of $\beta$-elemene were frequently required in order to reach the therapeutic effects $[11,12]$.

Nitric oxide (NO) is an important signaling and/or effector molecule involved in various physiological and pathophysiological processes [13]. High levels of NO exert its antitumor activity by inducing cell apoptosis, inhibiting tumor metastasis as well as sensitizing drug-resistant tumor cells to chemotherapy, radiation and immunotherapy in vitro and in vivo [14-16]. However, due to its short half-life and chemical instability, NO donors are usually employed as surrogates for NO in anticancer studies [17]. As an important class of NO donors, furoxans are able to produce high levels of NO in vitro and inhibit the growth of tumors in vivo [18]. In recent decade, numerous efforts were directed towards the construction of hybrids incorporating furoxan subunits to advance the pharmacological profile of the parent drug. Many studies have shown that (phenylsulfonyl)furoxanbased NO-releasing natural products possessed greater antitumor activity than corresponding parent compounds, furoxan precursors and/or their combinations in vitro and in vivo [19-22].

In order to improve the anticancer efficacy of natural $\beta$-elemene, based on the above findings, we hypothesized that hybridization of (phenylsulfonyl)furoxan and $\beta$-elemene might release high levels of NO to exert synergistic antitumor effects with $\beta$-elemene. Therefore, a series of hybrids (11a-f, 14, 18a-f) from such furoxan and $\beta$-elemene were designed and synthesized. Their antitumor activity in vitro and in vivo, NO-releasing ability and mechanism of anticancer action were biologically evaluated.

\section{Results and discussions}

\subsection{Chemistry}

The synthesis of compounds 11a-f was illustrated in Scheme 1. The substituted furoxans 6a-f were synthesized in a five-step sequence. The starting material benzenethiol $\mathbf{1}$ was treated with $\mathrm{NaOH}$ and chloroacetic acid under reflux to give 2-(phenylthio)acetic acid 2, which was oxidized with $30 \% \mathrm{H}_{2} \mathrm{O}_{2}$ to generate 2-(phenylsulfonyl)acetic acid $\mathbf{3}$, followed by treatment with fuming 
$\mathrm{HNO}_{3}$ to produce di(phenylsulfonyl)furoxan 4. Then, reaction of $\mathbf{4}$ with different diols gave mono(phenylsulfonyl)furoxans 5a-e, which were converted to $\mathbf{6 a - f}$ by treatment with corresponding anhydrides in the presence of DMAP/Et $3 \mathrm{~N}$. Chlorination of $\beta$-elemene (7) with $\mathrm{NaClO}$ produced the chlorinated mixture of $\mathbf{8} \mathbf{a}$ and $\mathbf{8 b}$, followed by treatment with $\mathrm{NaOAc}$ to give the acylated compounds $9 \mathbf{a}$ and $9 \mathbf{b}$. The resulting products were subjected to alkaline hydrolysis to give a mixture of $13-\beta$-elemol (10a) and $14-\beta$-elemol (10b), which was separated by HPLC to provide the main component 10a. Subsequent condensation of 10a and $\mathbf{6 a - f}$ afforded the target compounds 11af.

The preparation of compounds $\mathbf{1 4}$ and 18a-f was depicted in Scheme 2. Reaction of 10a with Boc- $L$-Asp in the presence of DCC and DMAP using dry DMF as the solvent generated intermediate 12 [23], followed by esterification with $\mathbf{5 b}$ to give intermediate $\mathbf{1 3}$, which was deprotected using trifluoroacetic acid (TFA) to provide compound 14. Similarly, condensation of 10a and varying Bocamino acids in dichloromethane produced intermediates 15a-f, followed by $\mathrm{N}$-Boc deprotection to give intermediates 16a-f. Treatment of $\mathbf{6 b}$ with oxalyl chloride formed intermediate 17, which reacted with 16a-f in the presence of DMAP/Et ${ }_{3} \mathrm{~N}$ to yield the title compounds 18a-f.
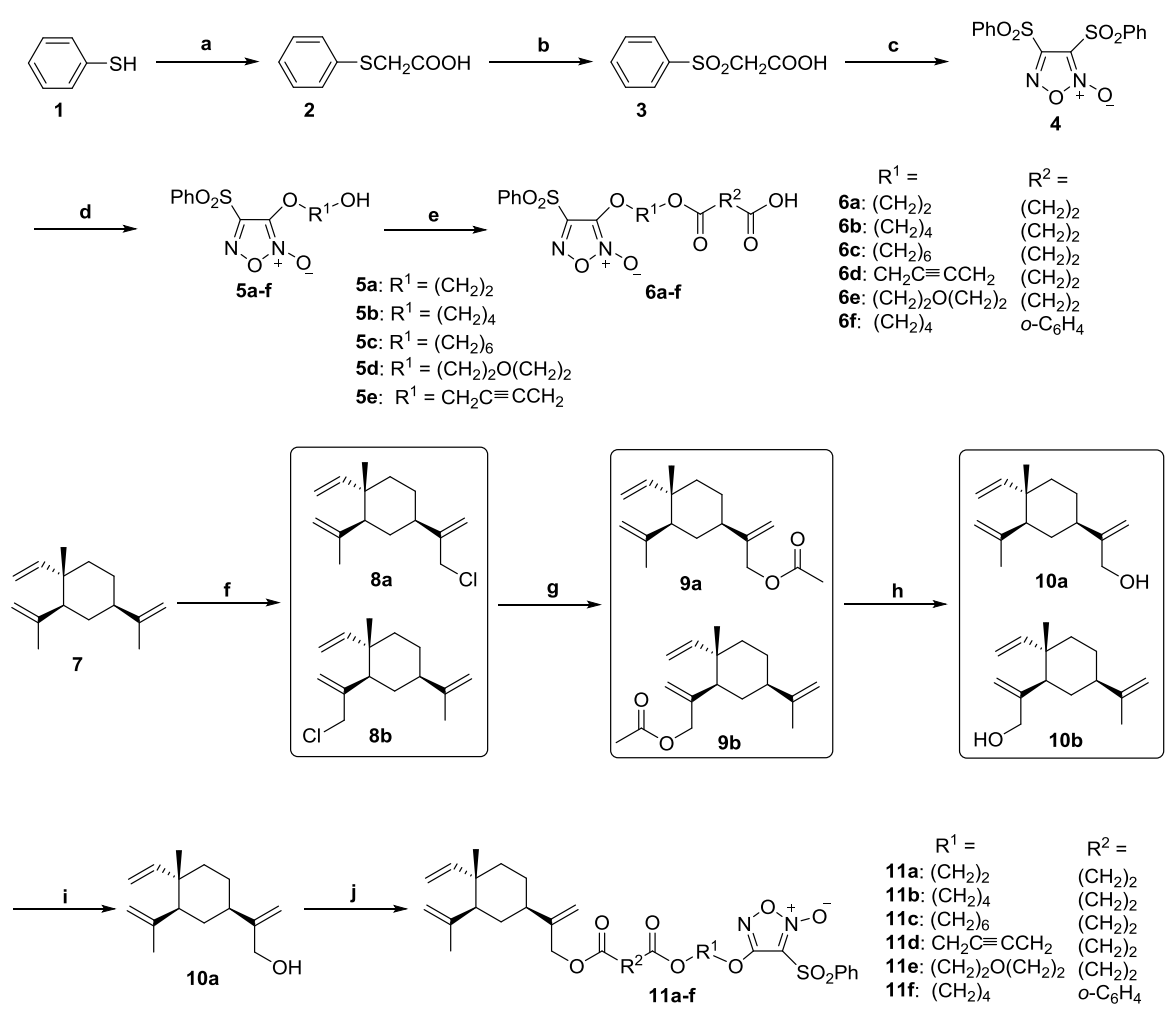

Scheme 1. Synthetic routes of the title compounds 11a-f. Reaction conditions and reagents: (a) chloroacetic acid, 5M NaOH, reflux, $2 \mathrm{~h}, 91 \%$; (b) $30 \% \mathrm{H}_{2} \mathrm{O}_{2}, \mathrm{AcOH}, \mathrm{rt}, 2 \mathrm{~h}$; (c) fuming $\mathrm{HNO}_{3}$, $\mathrm{AcOH}, 100{ }^{\circ} \mathrm{C}, 3 \mathrm{~h}, 75 \%$; (d) diols, $5 \mathrm{M} \mathrm{NaOH}, 0.5 \mathrm{~h}, 78-86 \%$; (e) anhydride, DMAP, $\mathrm{Et}_{3} \mathrm{~N}, \mathrm{CH}_{2} \mathrm{Cl}_{2}$, rt, 2 h, 84-93\%; (f) $\mathrm{NaClO}, \mathrm{HOAc} / \mathrm{CH}_{2} \mathrm{Cl}_{2}, 0-5{ }^{\circ} \mathrm{C}, 6 \mathrm{~h}, 55 \%$; (g) $\mathrm{NaOAc}, \mathrm{DMF}, 120^{\circ} \mathrm{C}, 8 \mathrm{~h}, 75 \%$; (h) $\mathrm{MeOH} / \mathrm{CHCl}_{3}, \mathrm{KOH}$, reflux, 2 h, 85\%; (i) Separated by HPLC, Hexane/EtOH = 98/2 (V/V), UV $=214 \mathrm{~nm}$; (j) 6a-f, EDCI, DMAP, rt, 4-8 h, 82-88\%. 


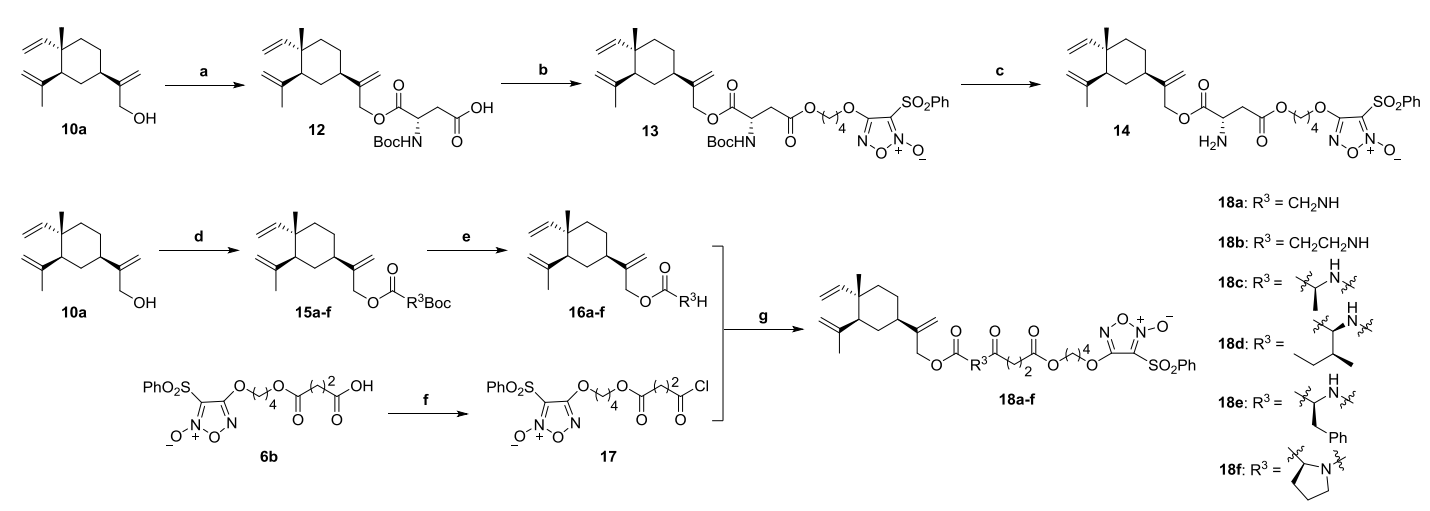

Scheme 2. Synthetic routes of the title compounds 14 and 18a-f. Reaction conditions and reagents: (a) Boc-L-Asp, DCC, DMAP, dry DMF, rt, 16 h, 62\%; (b) 5b, DCC, DMAP, rt, 8 h, 85\%; (c) TFA, $\mathrm{CH}_{2} \mathrm{Cl}_{2}, \mathrm{rt}, 1 \mathrm{~h}, 78 \%$; (d) Boc-amino acids, DCC, DMAP, rt, 4-10 h, 82-91\%; (e) TFA, $\mathrm{CH}_{2} \mathrm{Cl}_{2}, \mathrm{rt}$, 0.5-1.5 h, 77-84\%; (f) oxalyl chloride, Cat. DMF, $\mathrm{CH}_{2} \mathrm{Cl}_{2}$, rt, $1.5 \mathrm{~h}$; (g) DMAP, $\mathrm{Et}_{3} \mathrm{~N}, \mathrm{CH}_{2} \mathrm{Cl}_{2}$, rt, 1 $2 \mathrm{~h}, 45-67 \%$.

\subsection{In vitro antiproliferative activity}

Initially, compounds 11a-f were first prepared and tested for their antiproliferative effects on three cancer cell lines (SGC-7901: human gastric carcinoma; HeLa: human cervical adenocarcinoma; U87: human glioblastoma). The results were presented in Table 1. As expected, all of the synthesized compounds showed much more potent antiproliferative activities than $\beta$ elemene, and most of them were comparable or even superior to positive control cisplatin. Interestingly, these compounds exhibited excellent sensitivity to U87 cells with $\mathrm{IC}_{50}$ values ranging from 0.154 to $0.002 \mu \mathrm{M}$. It was found that improvement of the activity was acquired by decreasing the length of the diol chain from $\mathrm{C}_{6}$ to $\mathrm{C}_{2}(e . g .11 \mathrm{c}<11 \mathrm{~b}<11 \mathrm{a})$. Replacement of butane-1,4-diol (11b) with 2-butine-1,4-diol (11d) or diethylene glycol (11e) resulted in slightly increased activity in SGC-7901 and HeLa cells, whereas the activity markedly decreased in U87 cells. Surprisingly, change of succinic anhydride (11b) to $o$-phthalic anhydride (11f) led to dramatically decreased activity in all the three cell lines.

Considering that the poor oral bioavailability of $\beta$-elemene is one of the main factors that lead to its moderate antitumor activity, some amino acids were introduced into the linker to improve the druggability of $\beta$-elemene [23-26] and further investigated for the structure-activity relationships. As a result, compounds 14 and 18a-f were synthesized and evaluated for their antiproliferative activities against SGC-7901, HeLa and U87 cells. As depicted in Table 1, these compounds exhibited significantly improved activities compared to $\beta$-elemene, which were comparable or even superior to positive control cisplatin. Replacement of succinic anhydride (11b) with $L$-aspartic acid (14) strengthened the activity against SGC-7901 and HeLa cells, whereas the activity in U87 cells sharply decreased, suggesting that introduction of a polar amino group $\left(-\mathrm{NH}_{2}\right)$ into the linker was much detrimental for the cytotoxicity against U87 cells. Incorporating several other amino acids, such as glycine (18a), $\beta$-alanine (18b), $L$-alanine (18c), etc. into 11b had no significant effects on SGC-7901 and HeLa cells compared to 11b, while the activity in U87 cells remarkably diminished except 18d containing $L$-isoleucine. Extending the chain length from glycine (18a) to $\beta$-alanine (18b) resulted in 3 times increased activity in U87 cells. It was observed that substitution of varying lipophilic groups at $\alpha$-position of glycine (e.g. 18c-f) enhanced the activity at different levels, in particular, 18d showed over 17 times more potent activity than 18a in U87 cells, which was 
comparable to $\mathbf{1 1 b}$, but still 5 times less than 11a.

Among all target compounds, 11a exhibited the strongest antiproliferative activity against SGC-7901, HeLa, and U87 cells with $\mathrm{IC}_{50}$ values of 3.18, 4.94, and $0.002 \mu \mathrm{M}$, respectively, which were significantly superior to that of positive control cisplatin ( $\mathrm{IC}_{50}, 9.09,16.28$, and $21.39 \mu \mathrm{M}$, respectively). Moreover, 11a was further assayed with lower cytotoxicity in normal liver LO-2 cells $\left(\mathrm{IC}_{50}, 30.42 \mu \mathrm{M}\right)$. Thus, compound 11a was selected for subsequent anticancer mechanism and in vivo cancer xenograft mouse model studies.

Table 1

Antiproliferative activity $\left(\mathrm{IC}_{50}, \mu \mathrm{M}\right)$ of $\beta$-elemene derivatives against three cancer cell lines

\begin{tabular}{cccc}
\hline \multirow{2}{*}{ Compd. } & \multicolumn{3}{c}{ Cell lines $\left(\mathrm{IC}_{50}{ }^{\mathrm{a}}, \mu \mathrm{M}\right)$} \\
\cline { 2 - 4 } & SGC-7901 & HeLa & U87 \\
\hline -Elemene & $236.27 \pm 18.41$ & $213.51 \pm 15.23$ & $179.72 \pm 15.37$ \\
$\mathbf{1 1 a}$ & $3.18 \pm 0.22$ & $4.94 \pm 0.34$ & $0.002 \pm 0.0005$ \\
$\mathbf{1 1 b}$ & $8.76 \pm 0.53$ & $10.92 \pm 0.79$ & $0.007 \pm 0.0013$ \\
$\mathbf{1 1 c}$ & $22.86 \pm 1.64$ & $23.16 \pm 0.93$ & $0.154 \pm 0.0172$ \\
$\mathbf{1 1 d}$ & $4.97 \pm 0.72$ & $3.78 \pm 0.16$ & $0.085 \pm 0.0057$ \\
$\mathbf{1 1 e}$ & $4.66 \pm 0.25$ & $5.78 \pm 0.55$ & $0.024 \pm 0.0046$ \\
$\mathbf{1 1 f}$ & $27.81 \pm 2.08$ & $21.86 \pm 1.91$ & $0.081 \pm 0.0062$ \\
$\mathbf{1 4}$ & $2.92 \pm 0.21$ & $3.64 \pm 0.27$ & $0.124 \pm 0.0089$ \\
$\mathbf{1 8 a}$ & $15.31 \pm 1.36$ & $10.20 \pm 0.58$ & $0.173 \pm 0.0203$ \\
$\mathbf{1 8 b}$ & $7.78 \pm 0.49$ & $8.86 \pm 0.74$ & $0.058 \pm 0.0038$ \\
$\mathbf{1 8 c}$ & $11.81 \pm 0.97$ & $10.92 \pm 0.66$ & $0.114 \pm 0.0092$ \\
$\mathbf{1 8 d}$ & $3.66 \pm 0.26$ & $4.25 \pm 0.55$ & $0.010 \pm 0.0018$ \\
$\mathbf{1 8 d}$ & $9.97 \pm 0.85$ & $10.76 \pm 0.88$ & $0.061 \pm 0.0071$ \\
$\mathbf{1 8 f}$ & $9.49 \pm 0.77$ & $11.24 \pm 0.95$ & $0.055 \pm 0.0034$ \\
Cisplatin & $9.09 \pm 0.83$ & $16.28 \pm 1.06$ & $21.39 \pm 1.91$ \\
\hline
\end{tabular}

${ }^{\mathrm{a}} \mathrm{IC}_{50}$ : concentration of the test compound that inhibits $50 \%$ of cell growth. Data are expressed as the mean $\pm \mathrm{SD}(\mathrm{n}=3)$.

\subsection{Effects of NO on the antitumor activity}

To examine whether NO contributes to the antitumor activity, the levels of NO released by the test compounds in vitro were first detected and presented as that of nitrite by Griess assay. As shown in Figure 1A, all of the compounds produced high levels of NO with time. It was observed that the concentrations of released NO gradually decreased with the extension of the diol chain length (e.g. 11a > 11b > 11c), which was consist with the antiproliferative activity. Among these compounds, 11a, 14, 18d released higher NO levels than other compounds, while 11c and 11f exhibited the lowest NO-releasing ability, which might, at least in part, result in their relatively poor antiproliferative activities.

Subsequently, 11a was investigated for its inhibitory activity against U87 cells in the presence or absence of an NO scavenger, hemoglobin (Hb) or carboxy-PTIO (PTIO). U87 cells were pretreated with varying concentrations of $\mathrm{Hb}$ or PTIO for $2 \mathrm{~h}$ and then treated with $0.01 \mu \mathrm{M}$ 11a for another $72 \mathrm{~h}$. The effects of different treatments on the growth of U87 cells were determined by the MTT assay (Figure 1B). Treatment with 11a alone significantly inhibited the proliferation of U87 cells 
and this inhibitory effect was reduced dose-dependently by pretreatment with $\mathrm{Hb}$ or PTIO. These results demonstrated that NO generated by 11a enhanced its inhibition effect on U87 cell proliferation in vitro.

Furthermore, 10a, 6a as the two moieties of 11a and their equimolar combination were also examined for their antiproliferative activitities against U87 cells. As shown in Figure 2, the inhibitory effects of $10 \mathbf{a}\left(\mathrm{IC}_{50}=197.65 \mu \mathrm{M}\right), \mathbf{6 a}\left(\mathrm{IC}_{50}=32.24 \mu \mathrm{M}\right)$ and their combination $\left(\mathrm{IC}_{50}=\right.$ $22.53 \mu \mathrm{M})$ were much less potent than $11 \mathrm{a}\left(\mathrm{IC}_{50}=0.002 \mu \mathrm{M}\right)$, respectively. These results suggested that the excellent antitumor activity of 11a resulted from a synergic effect of $\beta$-elemene and NO donor moieties.
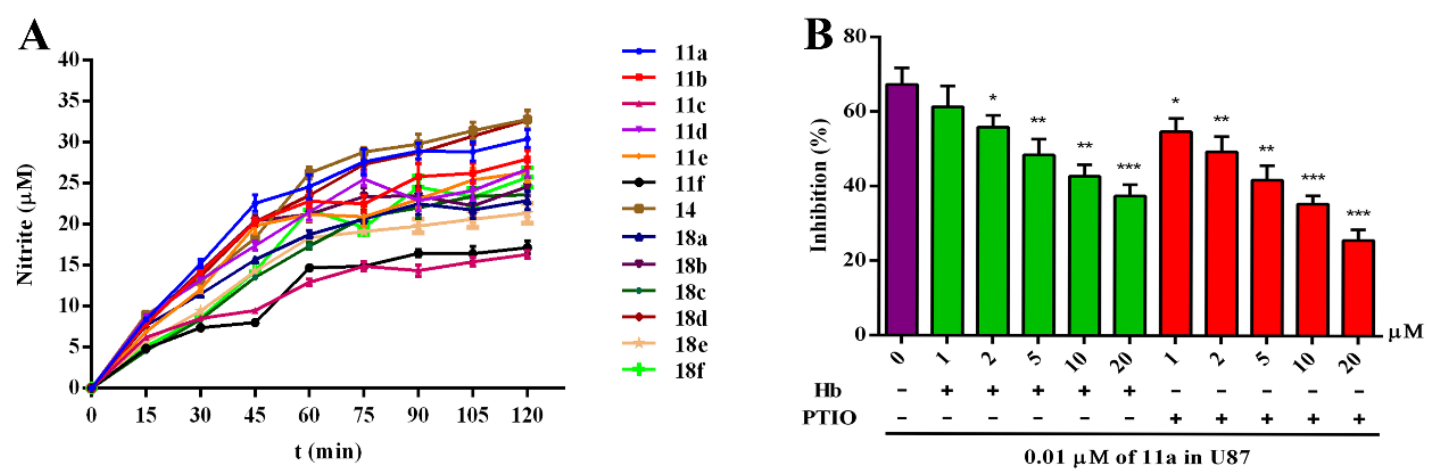

Figure 1. Effects of NO produced by the title compounds on the antitumor activity. (A) The levels of released NO for the test compounds were measured at $100 \mu \mathrm{M}$ over duration of 120 min by Griess assay. (B) Effect of hemoglobin (Hb) or carboxy-PTIO (PTIO) on the antiproliferative activity of 11a. U87 cells were pretreated with the indicated concentrations of $\mathrm{Hb}$ or PTIO for $2 \mathrm{~h}$ and then treated with $0.01 \mu \mathrm{M}$ of 11a for another $72 \mathrm{~h}$. Data are expressed as the mean $\pm \mathrm{SD}(\mathrm{n}=3)$. $* P<0.05, * * P<0.01, * * * P<0.001 v s$. the group without $\mathrm{Hb}$ or PTIO.

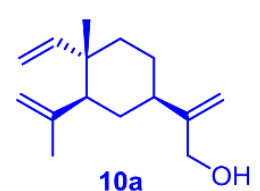

$\mathrm{IC}_{50}=197.65 \mu \mathrm{M}$

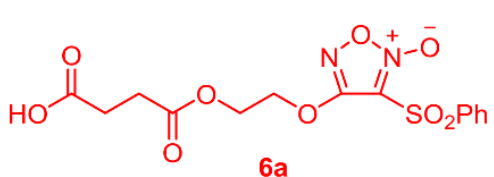

$\mathrm{IC}_{50}=32.24 \mu \mathrm{M}$

L

U87 cells

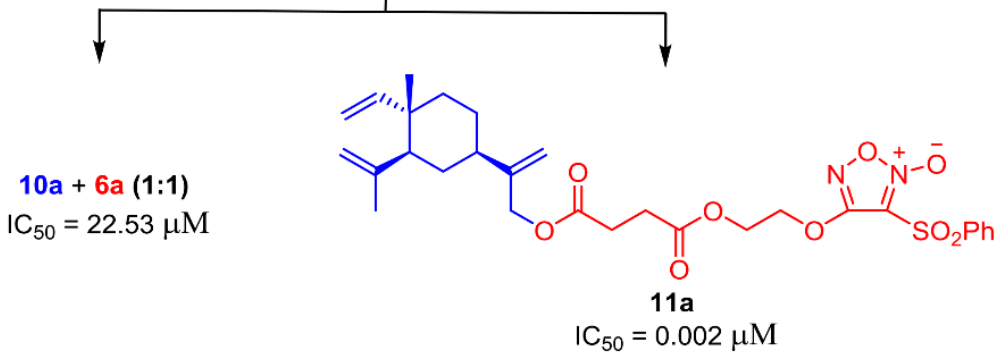

Figure 2. Antiproliferative activity of 11a in comparison with that of 10a, $\mathbf{6 a}$ and their equimolar combination in U87 cells.

\subsection{Effect of 11a on cell cycle}

To investigate whether 11a suppressed the cell growth by a cell-cycle arrest, the cell cycle 
distribution was analyzed by flow cytometry after staining of the DNA with propidium iodide (PI). As shown in Figure 3, 11a influenced cell cycle progression at low nanomolar concentrations. Treatment of U87 cells with 11a at concentrations of $0.5-2.0 \mathrm{nM}$ increased the percentage of cells at the $\mathrm{G} 2$ phase from $18.86 \%$ to $47.99 \%$ accompanying by a decrease in G1-phase cells from $54.11 \%$ to $26.96 \%$ in a dose-dependent manner, respectively. The results indicated that 11a caused the G2 phase arrest of the cell cycle in 11a-induced cell growth inhibition.
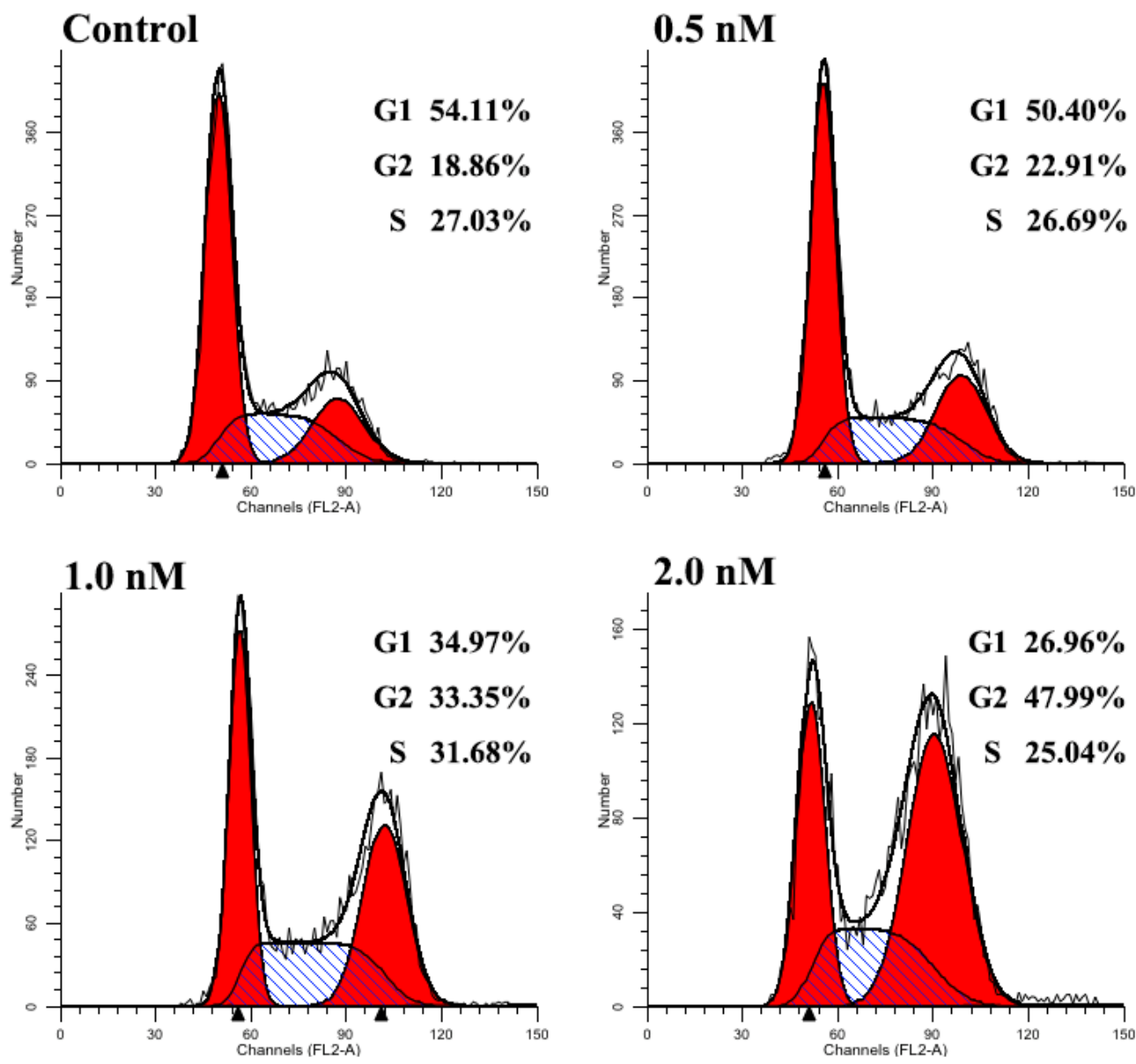

Figure 3. Effect of 11a on cell cycle progression of U87 cells. Treatment of U87 cells with 11a (0, $0.5,1.0,2.0 \mathrm{nM}$ ) for $72 \mathrm{~h}$, intracellular DNA was stained with propidium iodide (PI). Cell cycle distribution was analyzed by flow cytometry.

\subsection{Effect of 11a on cell apoptosis}

To determine the possible role of 11a in cell apoptosis, U87 cells were treated with different concentrations of 11a for $72 \mathrm{~h}$ and stained with Annexin V-APC/7-AAD. The percentages of apoptotic U87 cells were measured by flow cytometry. As depicted in Figure 4, 11a significantly induced apoptosis of U87 cells in a concentration-dependent manner. Treatment of U87 cells with 11a at concentrations of $0.5,1.0$ and $2.0 \mathrm{nM}$ for $72 \mathrm{~h}$ resulted in $18.32 \%, 34.94 \%$ and $53.70 \%$ apoptotic cells $(\mathrm{Q} 2+\mathrm{Q} 4)$, respectively, as compared with $6.84 \%$ in an untreated group. The results indicated that 11a exerted its antitumor activity potentially via the induction of cell apoptosis. 

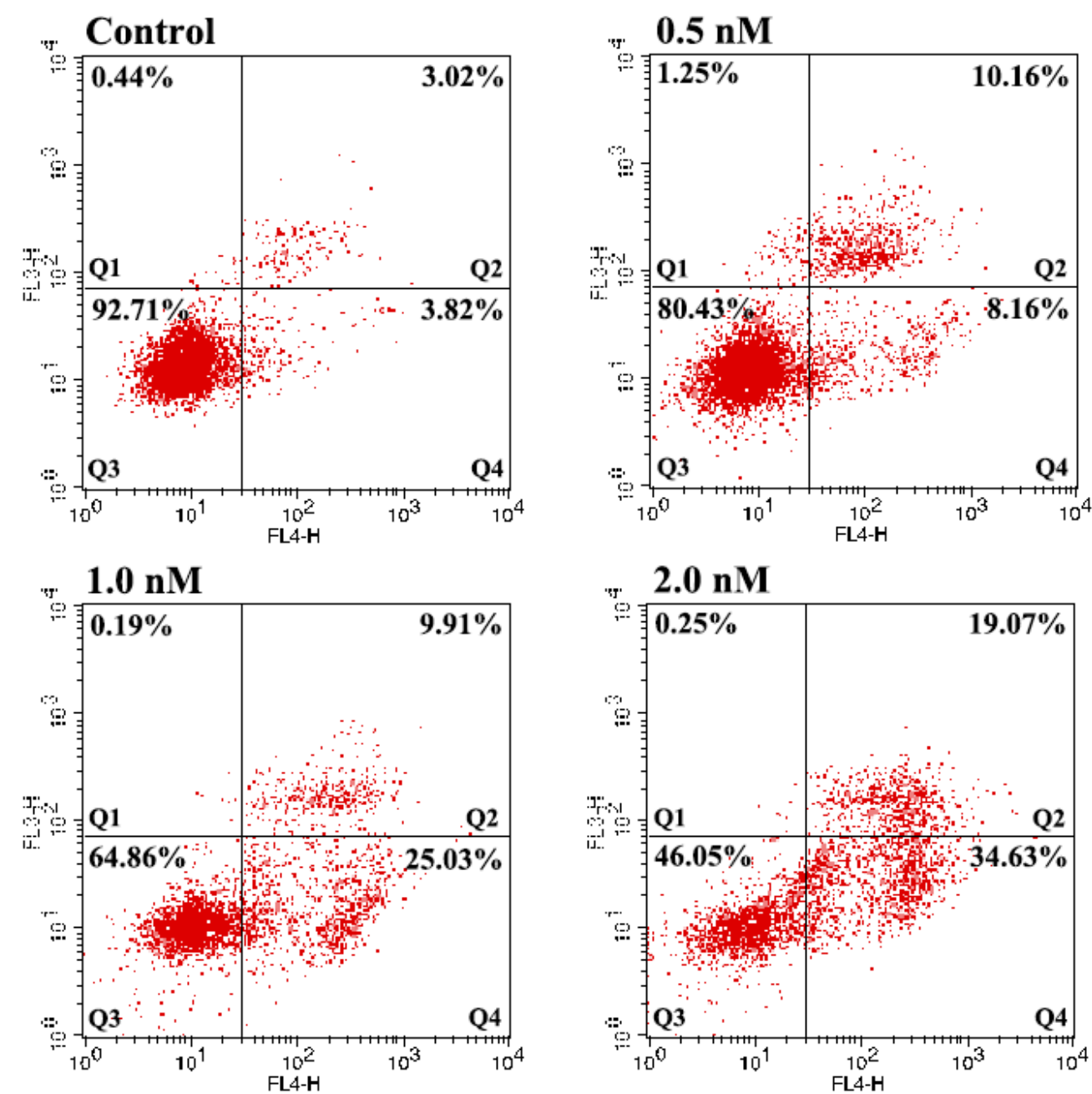

Figure 4. Effect of 11a on apoptosis of U87 cells. Treatment with 11a at the indicated concentrations for $72 \mathrm{~h}$, U87 cells were collected and stained with Annexin V-APC/7-AAD, followed by flow cytometric analysis.

\subsection{Effect of 11a on apoptosis-related proteins}

Akt plays a key role in regulating a diversity of cellular functions, such as protein synthesis, cell cycle, cell survival and apoptosis $[27,28]$. It has been reported that apoptosis might be prevented through the activation of the PI3K/Akt pathway in several cancer cells [29-32]. Activated Akt phosphorylates the intracellular protein Bad, resulting in the release of the anti-apoptotic protein Bcl-2, which contributes to cancer cell survival. Bax, a dominant-negative inhibitor of Bcl-2, induces a mitochondrial permeability transition and promotes apoptosis [33]. Caspase-3 acts as a final executor in apoptosis and can be irreversibly activated through cleavage of pro-caspase-3 [34]. As shown in Figure 5, 11a significantly inhibited p-Akt activation, Bcl-2 expression and promoted Bax expression, caspase-3 activation in concentration-dependent manners, while the total protein level of Akt was not altered. The results indicated that 11a induced apoptosis of U87 cells possibly through suppressing the activation of the PI3K/Akt pathway. 

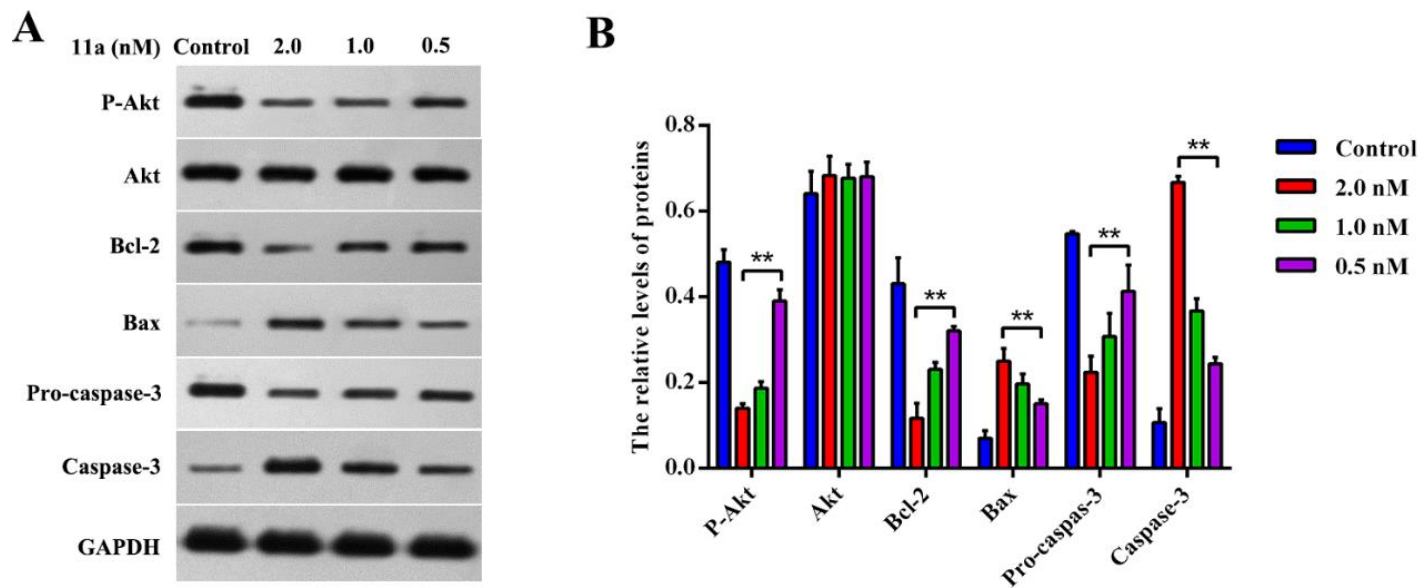

Figure 5. Effects of 11a on apoptosis-related proteins in U87 cells. U87 cells were treated with varying concentrations of 11a for $72 \mathrm{~h}$. (A) The expressions of p-Akt, Akt, Bcl-2, Bax, pro-caspase3 and caspase- 3 were determined by Western Blotting using specific antibodies. GAPDH was used as internal control; (B) The density ratios of proteins to GAPDH are shown as relative expression. Data are expressed as the mean $\pm \mathrm{SD}(\mathrm{n}=3)$. $* * P<0.01 v s$. control group.

\subsection{In vivo antitumor activity of 11 a}

To further evaluate the in vivo antitumor activity of 11a, human liver cancer xenograft was established by subcutaneous inoculation of $\mathrm{H} 22$ cells into the right flank of mice. 32 mice were then divided into four groups at random and administered intravenously with $60 \mathrm{mg} / \mathrm{kg} \beta$-elemene, 30 or $60 \mathrm{mg} / \mathrm{kg}$ 11a in a vehicle of $10 \% \mathrm{DMF} / 2 \%$ Tween $80 / 88 \%$ saline once a day, respectively. All the mice were sacrificed after three weeks, and the tumors were excised and weighed. As presented in Table 2, 11a markedly inhibited the tumor growth in a dose-dependent manner. At a dose of 60 $\mathrm{mg} / \mathrm{kg}$, 11a possessed a tumor inhibitory rate (TIR) of $64.8 \%$, which was significantly superior to $\beta$-elemene with a TIR of $49.6 \%$. Thus, 11a may deserve further investigation as a potential anticancer drug candidate.

Table 2. In vivo antitumor activity of 11a in H22 liver cancer xenograft mouse model

\begin{tabular}{|c|c|c|c|c|c|c|c|}
\hline \multirow[t]{2}{*}{ Drugs } & \multirow{2}{*}{$\begin{array}{c}\text { Dose } \\
\mathrm{mg} / \mathrm{kg}\end{array}$} & \multicolumn{2}{|c|}{$\begin{array}{c}\text { Number of } \\
\text { mice }\end{array}$} & \multicolumn{2}{|c|}{ Weight of mice (g) } & \multirow{2}{*}{$\begin{array}{c}\text { Weight of } \\
\text { tumor } X \pm S D \\
\text { (g) }\end{array}$} & \multirow{2}{*}{$\begin{array}{c}\text { Ratio of } \\
\text { inhibition } \\
\text { (\%) }\end{array}$} \\
\hline & & Start & End & Start & End & & \\
\hline Control $^{\mathrm{a}}$ & - & 8 & 8 & $18.0 \pm 0.2$ & $22.9 \pm 0.4$ & $5.68 \pm 0.49$ & \\
\hline$\beta$-Elemene & 60 & 8 & 8 & $18.1 \pm 0.1$ & $20.0 \pm 0.3$ & $2.86 \pm 0.27^{* *}$ & $49.6 \%$ \\
\hline \multirow{2}{*}{$11 \mathrm{a}$} & 30 & 8 & 8 & $18.2 \pm 0.2$ & $21.6 \pm 0.4$ & $2.83 \pm 0.19^{* *}$ & $50.2 \%$ \\
\hline & 60 & 8 & 8 & $18.0 \pm 0.2$ & $20.9 \pm 0.6$ & $2.00 \pm 0.16^{* *}$ & $64.8 \%$ \\
\hline
\end{tabular}

${ }^{a}$ Control: vehicle of $10 \% \mathrm{DMF} / 2 \%$ Tween $80 / 88 \%$ saline. $* * P<0.01 v s$. control group.

\section{Conclusion}

In summary, thirteen novel furoxan-based NO-donating $\beta$-elemene derivatives were synthesized and displayed much more potent antiproliferative activities than parent compound $\beta$-elemene against SGC-7901, HeLa and U87 cell lines, which are comparable or even superior to that of positive control cisplatin. Moreover, most compounds released high levels of NO in vitro, and the antitumor activity of 11a in U87 cells was remarkably diminished by an NO scavenger in a dose- 
dependent manner. Further mechanism studies showed that 11a blocked the G2 phase of the cell cycle and induced apoptosis through inhibiting the activation of the PI3K/Akt pathway. Finally, the in vivo antitumor activity of 11a was verified in $\mathrm{H} 22$ liver cancer xenograft mouse model. Collectively, the current finding may provide a new insight for the design of natural product-based drugs to enhance the efficacy of chemotherapy.

\section{Experimental section}

\subsection{Chemistry}

\subsubsection{General}

Most chemicals and solvents were purchased from commercial sources. Further purification and drying by standard methods were employed when necessary. ${ }^{1} \mathrm{H}$ NMR and ${ }^{13} \mathrm{C}$ NMR spectra were recorded on Bruker-300 spectrometers in the indicated solvents (TMS as internal standard). Data are reported as follows: chemical shift in ppm $(\delta)$, multiplicity $(\mathrm{s}=$ singlet, $\mathrm{d}=$ doublet, $\mathrm{t}=$ triplet, $\mathrm{q}=$ quartet, brs $=$ broad singlet, $\mathrm{m}=$ multiplet), coupling constant $(\mathrm{Hz})$, and integration. High Resolution Mass measurement was performed on Agilent QTOF 6520 mass spectrometer with electron spray ionization (ESI) as the ion source. Purity of all tested compounds was $\geq 95 \%$, as estimated by HPLC analysis. Flash column chromatography was carried out using commercially available silica gel (200-300 mesh) under pressure. Intermediates 6a-f [35] and 10a [36] were synthesized according to our reported procedures.

\subsubsection{General procedure for synthesis of the title compound 11a-f}

To a solution of 10a (44 mg, $0.2 \mathrm{mmol})$ in $\mathrm{CH}_{2} \mathrm{Cl}_{2}(5 \mathrm{~mL})$ was added $\mathbf{6}(0.24 \mathrm{mmol})$, EDCI (58 $\mathrm{mg}, 0.3 \mathrm{mmol}$ ), DMAP ( $3 \mathrm{mg}, 0.02 \mathrm{mmol}$ ), the mixture was stirred for $4-8 \mathrm{~h}$ at room temperature. The reaction mixture was then diluted with $\mathrm{CH}_{2} \mathrm{Cl}_{2}$, washed with $10 \% \mathrm{HCl}$, water, and brine successively, dried over anhydrous $\mathrm{Na}_{2} \mathrm{SO}_{4}$, and concentrated. The residue was purified by flash column chromatography using petroleum ether/ethyl acetate $(4 / 1, \mathrm{~V} / \mathrm{V})$ as an eluent to afford the title compounds.

\subsubsection{Compound 11a}

Colorless liquid, yield 84\%. ${ }^{1} \mathrm{H}$ NMR $\left(300 \mathrm{MHz}, \mathrm{CDCl}_{3}\right) \delta 8.13-8.01(\mathrm{~m}, 2 \mathrm{H}), 7.77(\mathrm{t}, J=7.5$ $\mathrm{Hz}, 1 \mathrm{H}), 7.64(\mathrm{t}, J=7.7 \mathrm{~Hz}, 2 \mathrm{H}), 5.81(\mathrm{dd}, J=17.8,10.5 \mathrm{~Hz}, 1 \mathrm{H}), 5.05(\mathrm{~s}, 1 \mathrm{H}), 5.01$ (s, 1H), 4.93 $(\mathrm{d}, J=3.3 \mathrm{~Hz}, 1 \mathrm{H}), 4.88(\mathrm{~d}, J=1.2 \mathrm{~Hz}, 1 \mathrm{H}), 4.82(\mathrm{~s}, 1 \mathrm{H}), 4.66-4.57(\mathrm{~m}, 5 \mathrm{H}), 4.56-4.50(\mathrm{~m}, 2 \mathrm{H})$, $2.72(\mathrm{~s}, 4 \mathrm{H}), 2.10-1.95(\mathrm{~m}, 2 \mathrm{H}), 1.71(\mathrm{~s}, 3 \mathrm{H}), 1.69-1.55(\mathrm{~m}, 3 \mathrm{H}), 1.53-1.40(\mathrm{~m}, 3 \mathrm{H}), 1.00(\mathrm{~s}$, $3 \mathrm{H}) ;{ }^{13} \mathrm{C}$ NMR (75 MHz, $\left.\mathrm{CDCl}_{3}\right) \delta 171.53,171.38,158.18,149.50,147.70,146.88,137.51,135.19$, 129.20, 128.14, 111.77, 110.43, 109.56, 68.35, 65.93, 60.92, 52.10, 41.21, 39.28(2), 32.48, 28.49, 28.40, 26.51, 24.33, 16.07; HRMS (ESI) calculated for $\mathrm{C}_{29} \mathrm{H}_{36} \mathrm{~N}_{2} \mathrm{NaO}_{9} \mathrm{~S}[\mathrm{M}+\mathrm{Na}]^{+} 611.2034$, found 611.2038 .

\subsubsection{Compound 11b}

Colorless liquid, yield 87\%. ${ }^{1} \mathrm{H}$ NMR $\left(300 \mathrm{MHz}, \mathrm{CDCl}_{3}\right) \delta 8.12-8.01(\mathrm{~m}, 2 \mathrm{H}), 7.77(\mathrm{dd}, J=$ 10.7, $4.3 \mathrm{~Hz}, 1 \mathrm{H}), 7.63(\mathrm{t}, J=7.7 \mathrm{~Hz}, 2 \mathrm{H}), 5.81(\mathrm{dd}, J=17.8,10.5 \mathrm{~Hz}, 1 \mathrm{H}), 5.05(\mathrm{~s}, 1 \mathrm{H}), 5.01(\mathrm{~s}$, $1 \mathrm{H}), 4.93(\mathrm{~d}, J=3.4 \mathrm{~Hz}, 1 \mathrm{H}), 4.88(\mathrm{~d}, J=1.0 \mathrm{~Hz}, 1 \mathrm{H}), 4.82(\mathrm{~s}, 1 \mathrm{H}), 4.61(\mathrm{~s}, 2 \mathrm{H}), 4.58(\mathrm{~s}, 1 \mathrm{H}), 4.46$ $(\mathrm{t}, J=6.2 \mathrm{~Hz}, 2 \mathrm{H}), 4.20(\mathrm{t}, J=6.2 \mathrm{~Hz}, 2 \mathrm{H}), 2.76-2.62(\mathrm{~m}, 4 \mathrm{H}), 2.08-1.91(\mathrm{~m}, 4 \mathrm{H}), 1.90-1.75$ $(\mathrm{m}, 2 \mathrm{H}), 1.71(\mathrm{~s}, 3 \mathrm{H}), 1.69-1.55(\mathrm{~m}, 3 \mathrm{H}), 1.53-1.41(\mathrm{~m}, 3 \mathrm{H}), 1.00(\mathrm{~s}, 3 \mathrm{H}) ;{ }^{13} \mathrm{C}$ NMR $(75 \mathrm{MHz}$, $\left.\mathrm{CDCl}_{3}\right) \delta 171.77,171.52,158.42,149.50,147.72,146.88,137.52,135.16,129.20,128.05,111.77$, 110.41, 109.56, 70.44, 65.88, 63.41, 52.10, 41.21, 39.28(2), 32.50, 28.61, 28.53, 26.52, 24.69, 24.49, 24.34, 16.07; HRMS (ESI) calculated for $\mathrm{C}_{31} \mathrm{H}_{40} \mathrm{~N}_{2} \mathrm{NaO}_{9} \mathrm{~S}[\mathrm{M}+\mathrm{Na}]^{+}$639.2347, found 639.2347. 


\subsubsection{Compound 11c}

Colorless liquid, yield 85\%. ${ }^{1} \mathrm{H}$ NMR $\left(300 \mathrm{MHz}, \mathrm{CDCl}_{3}\right) \delta 8.06(\mathrm{~d}, J=7.5 \mathrm{~Hz}, 2 \mathrm{H}), 7.76(\mathrm{t}, J=$ $7.5 \mathrm{~Hz}, 1 \mathrm{H}), 7.62(\mathrm{t}, J=7.9 \mathrm{~Hz}, 2 \mathrm{H}), 5.81(\mathrm{dd}, J=17.7,10.5 \mathrm{~Hz}, 1 \mathrm{H}), 5.05(\mathrm{~s}, 1 \mathrm{H}), 5.01(\mathrm{~s}, 1 \mathrm{H})$, $4.93(\mathrm{~d}, J=4.5 \mathrm{~Hz}, 1 \mathrm{H}), 4.88(\mathrm{~s}, 1 \mathrm{H}), 4.82(\mathrm{~s}, 1 \mathrm{H}), 4.60(\mathrm{~s}, 2 \mathrm{H}), 4.58(\mathrm{~s}, 1 \mathrm{H}), 4.42(\mathrm{t}, J=6.5 \mathrm{~Hz}$, $2 \mathrm{H}), 4.12(\mathrm{t}, J=6.5 \mathrm{~Hz}, 2 \mathrm{H}), 2.72-2.61(\mathrm{~m}, 4 \mathrm{H}), 2.09-1.96(\mathrm{~m}, 2 \mathrm{H}), 1.94-1.82(\mathrm{~m}, 2 \mathrm{H}), 1.71$ (s, 3H), $1.69-1.57(\mathrm{~m}, 6 \mathrm{H}), 1.51-1.42(\mathrm{~m}, 6 \mathrm{H}), 1.00(\mathrm{~s}, 3 \mathrm{H}) ;{ }^{13} \mathrm{C} \mathrm{NMR}\left(75 \mathrm{MHz}, \mathrm{CDCl}_{3}\right) \delta 172.19$, $171.92,158.93,149.90,148.17,147.26,138.07,135.50,129.55,128.42,112.17,110.86,109.94$, 71.33, 66.26, 64.45, 52.57, 41.67, 39.71, 39.64, 32.94, 29.09, 29.01, 28.37, 28.23, 26.95, 25.36, 25.18, 24.70, 16.51; HRMS (ESI) calculated for $\mathrm{C}_{33} \mathrm{H}_{44} \mathrm{~N}_{2} \mathrm{NaO}_{9} \mathrm{~S}[\mathrm{M}+\mathrm{Na}]^{+} 667.2660$, found 667.2676 .

\subsubsection{Compound 11d}

Colorless liquid, yield 78\%. ${ }^{1} \mathrm{H}$ NMR $\left(300 \mathrm{MHz}, \mathrm{CDCl}_{3}\right) \delta 8.08(\mathrm{~d}, J=7.9 \mathrm{~Hz}, 2 \mathrm{H}), 7.77(\mathrm{t}, J=$ $6.8 \mathrm{~Hz}, 1 \mathrm{H}), 7.64(\mathrm{t}, J=7.1 \mathrm{~Hz}, 2 \mathrm{H}), 5.82(\mathrm{dd}, J=17.2,10.7 \mathrm{~Hz}, 1 \mathrm{H}), 5.10(\mathrm{~s}, 2 \mathrm{H}), 5.05(\mathrm{~s}, 1 \mathrm{H})$, $5.02(\mathrm{~s}, 1 \mathrm{H}), 4.93(\mathrm{~d}, J=3.8 \mathrm{~Hz}, 1 \mathrm{H}), 4.88(\mathrm{~s}, 1 \mathrm{H}), 4.83(\mathrm{~s}, 1 \mathrm{H}), 4.77(\mathrm{~s}, 2 \mathrm{H}), 4.62(\mathrm{~s}, 2 \mathrm{H}), 4.59(\mathrm{~s}$, $1 \mathrm{H}), 2.71(\mathrm{~s}, 4 \mathrm{H}), 2.09-1.95(\mathrm{~m}, 2 \mathrm{H}), 1.71(\mathrm{~s}, 3 \mathrm{H}), 1.64-1.54(\mathrm{~m}, 3 \mathrm{H}), 1.53-1.41(\mathrm{~m}, 3 \mathrm{H}), 1.01$ (s, 3H); ${ }^{13} \mathrm{C}$ NMR $\left(75 \mathrm{MHz}, \mathrm{CDCl}_{3}\right) \delta 171.65,171.35,157.86,149.91,148.14,147.27,137.81$, 135.64, 129.64, 128.57, 112.20, 110.95, 109.97, 83.74, 78.61, 66.39, 58.52, 52.59, 52.04, 41.70, $39.73,39.66,32.96,28.90,28.74,26.97,24.70,16.53$; HRMS (ESI) calculated for $\mathrm{C}_{31} \mathrm{H}_{36} \mathrm{~N}_{2} \mathrm{NaO}_{9} \mathrm{~S}$ $[\mathrm{M}+\mathrm{Na}]^{+}$635.2034, found 635.2049.

\subsubsection{Compound 11e}

Colorless liquid, yield 80\%. ${ }^{1} \mathrm{H}$ NMR $\left(300 \mathrm{MHz}, \mathrm{CDCl}_{3}\right) \delta 8.14-8.03(\mathrm{~m}, 2 \mathrm{H}), 7.77(\mathrm{t}, J=7.5$ $\mathrm{Hz}, 1 \mathrm{H}), 7.63(\mathrm{t}, J=7.7 \mathrm{~Hz}, 2 \mathrm{H}), 5.81(\mathrm{dd}, J=17.8,10.5 \mathrm{~Hz}, 1 \mathrm{H}), 5.04$ (s, 1H), 5.00 (s, 1H), 4.93 $(\mathrm{d}, J=3.6 \mathrm{~Hz}, 1 \mathrm{H}), 4.88(\mathrm{~s}, 1 \mathrm{H}), 4.82(\mathrm{~s}, 1 \mathrm{H}), 4.65-4.52(\mathrm{~m}, 5 \mathrm{H}), 4.30(\mathrm{t}, J=4.7 \mathrm{~Hz}, 2 \mathrm{H}), 3.92(\mathrm{t}$, $J=4.4 \mathrm{~Hz}, 2 \mathrm{H}), 3.80(\mathrm{t}, J=4.7 \mathrm{~Hz}, 2 \mathrm{H}), 2.69(\mathrm{~s}, 4 \mathrm{H}), 2.08-1.96(\mathrm{~m}, 2 \mathrm{H}), 1.71(\mathrm{~s}, 3 \mathrm{H}), 1.69-1.56$ (m, 3H), $1.54-1.41(\mathrm{~m}, 3 \mathrm{H}), 1.00(\mathrm{~s}, 3 \mathrm{H}) ;{ }^{13} \mathrm{C} \mathrm{NMR}\left(75 \mathrm{MHz}, \mathrm{CDCl}_{3}\right) \delta 171.79,171.48,158.41$, $149.51,147.72,146.87,137.51,135.18,129.19,128.08,111.76,110.38,109.55,70.03,68.86,67.84$, $65.83,63.19,52.08,41.17,39.27(2), 32.48,28.55,28.43,26.50,24.35,16.06$; HRMS (ESI) calculated for $\mathrm{C}_{31} \mathrm{H}_{40} \mathrm{~N}_{2} \mathrm{NaO}_{10} \mathrm{~S}[\mathrm{M}+\mathrm{Na}]^{+}$655.2296, found 655.2299.

\subsubsection{Compound 11f}

Colorless liquid, yield 81\%. ${ }^{1} \mathrm{H}$ NMR $\left(300 \mathrm{MHz}, \mathrm{CDCl}_{3}\right) \delta 8.16-7.99(\mathrm{~m}, 2 \mathrm{H}), 7.86-7.77(\mathrm{~m}$, $1 \mathrm{H}), 7.77-7.65(\mathrm{~m}, 2 \mathrm{H}), 7.67-7.53(\mathrm{~m}, 4 \mathrm{H}), 5.82(\mathrm{dd}, J=17.8,10.5 \mathrm{~Hz}, 1 \mathrm{H}), 5.15(\mathrm{~s}, 1 \mathrm{H}), 5.07$ (s, 1H), $4.94(\mathrm{~d}, J=3.4 \mathrm{~Hz}, 1 \mathrm{H}), 4.89(\mathrm{~d}, J=1.0 \mathrm{~Hz}, 1 \mathrm{H}), 4.84(\mathrm{~s}, 3 \mathrm{H}), 4.59$ (s, 1H), 4.48 (t, $J=5.9$ $\mathrm{Hz}, 2 \mathrm{H}), 4.41(\mathrm{t}, J=5.9 \mathrm{~Hz}, 2 \mathrm{H}), 2.16-1.88(\mathrm{~m}, 6 \mathrm{H}), 1.71(\mathrm{~s}, 3 \mathrm{H}), 1.70-1.56(\mathrm{~m}, 3 \mathrm{H}), 1.55-1.42$ $(\mathrm{m}, 3 \mathrm{H}), 1.01$ (s, 3H); ${ }^{13} \mathrm{C} \mathrm{NMR}\left(75 \mathrm{MHz}, \mathrm{CDCl}_{3}\right) \delta 167.23,166.53,158.42,149.47,147.52,146.87$, $137.53,135.15,131.96,131.10,130.87,130.58,129.20,128.55,128.28,128.03,111.78,110.79$, 109.59, 70.43, 66.77, 64.39, 52.10, 41.22, 39.26(2), 32.53, 26.52, 24.80, 24.43, 24.35, 16.07; HRMS (ESI) calculated for $\mathrm{C}_{35} \mathrm{H}_{40} \mathrm{~N}_{2} \mathrm{NaO}_{9} \mathrm{~S}[\mathrm{M}+\mathrm{Na}]^{+}$687.2347, found 687.2345.

\subsubsection{Synthesis of the title compound 14}

To a solution of $\mathbf{1 0 a}(88 \mathrm{mg}, 0.4 \mathrm{mmol})$ in anhydrous DMF $(8 \mathrm{~mL})$ was added Boc- $L$-aspartic acid (280 mg, $1.2 \mathrm{mmol})$, DCC (91 mg, $0.44 \mathrm{mmol}$ ), DMAP (0.04 mmol, $5 \mathrm{mg}$ ), the mixture was stirred for $16 \mathrm{~h}$ at room temperature. The reaction mixture was added $8 \mathrm{~mL} \mathrm{H}_{2} \mathrm{O}$ and extracted with ethyl acetate $(15 \mathrm{~mL} \times 3)$. The combined organic extracts were washed with water $(10 \mathrm{~mL} \times 2)$, dried over anhydrous $\mathrm{Na}_{2} \mathrm{SO}_{4}$ and concentrated to give the crude intermediate 12 in $62 \%$ yield without further purification [23]. 
12 (87 mg, $0.2 \mathrm{mmol}$ ), $5 \mathbf{b}$ (76 mg, $0.24 \mathrm{mmol}$ ), DCC (46 mg, $0.22 \mathrm{mmol}$ ) and DMAP (3 mg, 0.02 mmol) were added in $\mathrm{CH}_{2} \mathrm{Cl}_{2}(5 \mathrm{~mL})$ and stirred for $6 \mathrm{~h}$ at room temperature. The reaction mixture was then diluted with $\mathrm{CH}_{2} \mathrm{Cl}_{2}$, washed with $10 \% \mathrm{HCl}$, water, dried over anhydrous $\mathrm{Na}_{2} \mathrm{SO}_{4}$, and concentrated. The residue was purified by flash column chromatography using petroleum ether/ethyl acetate $(10 / 1, \mathrm{~V} / \mathrm{V})$ as an eluent to obtain intermediate $\mathbf{1 3}$ as yellowish liquid, yield $85 \%$. ${ }^{1} \mathrm{H} \mathrm{NMR}\left(300 \mathrm{MHz}, \mathrm{CDCl}_{3}\right) \delta 8.07(\mathrm{~d}, J=7.4 \mathrm{~Hz}, 2 \mathrm{H}), 7.77(\mathrm{t}, J=7.5 \mathrm{~Hz}, 1 \mathrm{H}), 7.63(\mathrm{t}, J=7.7 \mathrm{~Hz}$, 2H), $5.81(\mathrm{dd}, J=17.8,10.5 \mathrm{~Hz}, 1 \mathrm{H}), 5.52(\mathrm{~d}, J=8.6 \mathrm{~Hz}, 1 \mathrm{H}), 5.05(\mathrm{~s}, 1 \mathrm{H}), 5.02(\mathrm{~s}, 1 \mathrm{H}), 4.93(\mathrm{~d}, J$ $=2.7 \mathrm{~Hz}, 1 \mathrm{H}), 4.88(\mathrm{~d}, J=1.9 \mathrm{~Hz}, 1 \mathrm{H}), 4.82(\mathrm{~s}, 1 \mathrm{H}), 4.73-4.54(\mathrm{~m}, 4 \mathrm{H}), 4.45(\mathrm{t}, J=6.1 \mathrm{~Hz}, 2 \mathrm{H})$, $4.19(\mathrm{t}, J=6.2 \mathrm{~Hz}, 2 \mathrm{H}), 3.10-2.80(\mathrm{~m}, 4 \mathrm{H}), 2.10-1.91(\mathrm{~m}, 2 \mathrm{H}), 1.90-1.75(\mathrm{~m}, 2 \mathrm{H}), 1.70(\mathrm{~s}, 3 \mathrm{H})$, $1.68-1.52(\mathrm{~m}, 3 \mathrm{H}), 1.45(\mathrm{~s}, 12 \mathrm{H}), 1.00(\mathrm{~s}, 3 \mathrm{H}) ; \mathrm{MS}(\mathrm{ESI}) \mathrm{m} / \mathrm{z}: 732.0[\mathrm{M}+\mathrm{H}]^{+} ; 749.2\left[\mathrm{M}+\mathrm{NH}_{4}\right]^{+}$; $766.0[\mathrm{M}+\mathrm{Cl}]^{-}$.

To a solution of $\mathbf{1 3}(125 \mathrm{mg}, 0.17 \mathrm{mmol})$ in $5 \mathrm{~mL} \mathrm{CH}_{2} \mathrm{Cl}_{2}, 0.5 \mathrm{~mL}$ trifluoroacetic acid was dropwise added and stirred at room temperature for $1 \mathrm{~h}$. The reaction solution was concentrated, and the residue was purified by flash column chromatography using $\mathrm{CH}_{2} \mathrm{Cl}_{2} / \mathrm{MeOH}(50 / 1, \mathrm{~V} / \mathrm{V})$ as an eluent to afford the title compound $\mathbf{1 4}$ as yellowish liquid, yield $78 \% .{ }^{1} \mathrm{H} \mathrm{NMR}\left(300 \mathrm{MHz}, \mathrm{CDCl}_{3}\right)$ $\delta 8.12-8.00(\mathrm{~m}, 2 \mathrm{H}), 7.77(\mathrm{t}, J=7.5 \mathrm{~Hz}, 1 \mathrm{H}), 7.63(\mathrm{t}, J=7.7 \mathrm{~Hz}, 2 \mathrm{H}), 5.81(\mathrm{dd}, J=17.8,10.5 \mathrm{~Hz}$, $1 \mathrm{H}), 5.05(\mathrm{~s}, 1 \mathrm{H}), 5.03(\mathrm{~s}, 1 \mathrm{H}), 4.93(\mathrm{~d}, J=3.1 \mathrm{~Hz}, 1 \mathrm{H}), 4.88(\mathrm{~d}, J=1.4 \mathrm{~Hz}, 1 \mathrm{H}), 4.83(\mathrm{~s}, 1 \mathrm{H}), 4.64$ (s, 2H), $4.58(\mathrm{~s}, 1 \mathrm{H}), 4.46(\mathrm{t}, J=6.1 \mathrm{~Hz}, 2 \mathrm{H}), 4.21(\mathrm{t}, J=6.2 \mathrm{~Hz}, 2 \mathrm{H}), 3.95-3.85(\mathrm{~m}, 1 \mathrm{H}), 2.92-$ $2.71(\mathrm{~m}, 2 \mathrm{H}), 2.05(\mathrm{~s}, 2 \mathrm{H}), 2.03-1.90(\mathrm{~m}, 4 \mathrm{H}), 1.89-1.77(\mathrm{~m}, 2 \mathrm{H}), 1.71(\mathrm{~s}, 3 \mathrm{H}), 1.68-1.56(\mathrm{~m}$, $3 \mathrm{H}), 1.54-1.42(\mathrm{~m}, 3 \mathrm{H}), 1.00(\mathrm{~s}, 3 \mathrm{H}) ;{ }^{13} \mathrm{C}$ NMR $\left(75 \mathrm{MHz}, \mathrm{CDCl}_{3}\right) \delta 173.28,170.63,158.42,149.41$, 147.46, 146.83, 137.50, 135.16, 129.20, 128.04, 111.79, 110.77, 109.61, 70.41, 66.43, 63.55, 52.10, 50.77, 41.25, 39.24(2), 38.25, 32.50, 26.51, 24.69, 24.47, 24.34, 16.07; HRMS (ESI) calculated for $\mathrm{C}_{31} \mathrm{H}_{42} \mathrm{~N}_{3} \mathrm{NaO}_{9} \mathrm{~S}[\mathrm{M}+\mathrm{H}]^{+}$632.2636, found 632.2639.

\subsubsection{General procedure for synthesis of the title compounds 18a-f 4.1.4.1. Synthesis of intermediates 15a-f}

To a solution of 10a ( $88 \mathrm{mg}, 0.4 \mathrm{mmol}$ ) in $\mathrm{CH}_{2} \mathrm{Cl}_{2}(5 \mathrm{~mL})$ was added corresponding Boc-amino acid (0.48 mmol), DCC (58 mg, $0.44 \mathrm{mmol})$, DMAP ( $5 \mathrm{mg}, 0.04 \mathrm{mmol})$, the mixture was stirred for 4-10 $\mathrm{h}$ at room temperature. The reaction mixture was then diluted with $\mathrm{CH}_{2} \mathrm{Cl}_{2}$, washed with $10 \%$ $\mathrm{HCl}$, water, dried over anhydrous $\mathrm{Na}_{2} \mathrm{SO}_{4}$, and concentrated. The residue was purified by flash column chromatography using petroleum ether/ethyl acetate $(10 / 1, \mathrm{~V} / \mathrm{V})$ as an eluent to give intermediates 15a-f as yellowish liquid, yield $82-91 \%$.

\subsubsection{Synthesis of intermediates $16 a-f$}

To a solution of $15(0.3 \mathrm{mmol})$ in $\mathrm{CH}_{2} \mathrm{Cl}_{2}(5 \mathrm{~mL}), 0.5 \mathrm{~mL}$ trifluoroacetic acid was dropwise added and stirred at room temperature for 0.5-1.5 h. The reaction solution was concentrated, and the residue was purified by flash column chromatography using $\mathrm{CH}_{2} \mathrm{Cl}_{2} / \mathrm{MeOH}(40 / 1, \mathrm{~V} / \mathrm{V})$ as an eluent to give intermediates 16a-f as yellowish liquid, yield 77-84\%.

\subsubsection{Synthesis of intermediate 17}

To a solution of $\mathbf{6 b}(124 \mathrm{mg}, 0.3 \mathrm{mmol})$ in $\mathrm{CH}_{2} \mathrm{Cl}_{2}(5 \mathrm{~mL})$ were added oxalyl chloride ( $37 \mu \mathrm{L}$, $0.45 \mathrm{mmol}$ ) and a catalytic amount of DMF, the mixture was stirred at room temperature for $1.5 \mathrm{~h}$ and then concentrated to yield intermediate $\mathbf{1 7}$ as yellowish liquid without further purification.

\subsubsection{Synthesis of compounds $18 \mathrm{a}-\mathrm{f}$}

A mixture of $16(0.2 \mathrm{mmol})$, DMAP $(3 \mathrm{mg}, 0.02 \mathrm{mmol})$, triethylamine $(83 \mu \mathrm{L}, 0.6 \mathrm{mmol})$ in $\mathrm{CH}_{2} \mathrm{Cl}_{2}(5 \mathrm{~mL})$ were dropwise added a $2 \mathrm{~mL} \mathrm{CH}_{2} \mathrm{Cl}_{2}$ solution of $\mathbf{1 7}(0.3 \mathrm{mmol})$ and stirred at room temperature for 1-2 $\mathrm{h}$. The reaction mixture was then diluted with $\mathrm{CH}_{2} \mathrm{Cl}_{2}$, washed with $10 \% \mathrm{HCl}$, 
water, dried over anhydrous $\mathrm{Na}_{2} \mathrm{SO}_{4}$, and concentrated. The residue was purified by flash column chromatography using petroleum ether/ethyl acetate $(2 / 1, \mathrm{~V} / \mathrm{V})$ as an eluent to afford the title compounds.

\subsection{Compound 18a}

Yellowish liquid, yield 49\%. ${ }^{1} \mathrm{H}$ NMR $\left(300 \mathrm{MHz}, \mathrm{CDCl}_{3}\right) \delta 8.06(\mathrm{~d}, J=7.3 \mathrm{~Hz}, 2 \mathrm{H}), 7.76(\mathrm{t}, J=$ $7.4 \mathrm{~Hz}, 1 \mathrm{H}), 7.63(\mathrm{t}, J=7.6 \mathrm{~Hz}, 2 \mathrm{H}), 6.19(\mathrm{~s}, 1 \mathrm{H}), 5.81(\mathrm{dd}, J=17.8,10.6 \mathrm{~Hz}, 1 \mathrm{H}), 5.05(\mathrm{~s}, 1 \mathrm{H})$, $5.03(\mathrm{~s}, 1 \mathrm{H}), 4.93(\mathrm{~d}, J=3.3 \mathrm{~Hz}, 1 \mathrm{H}), 4.88(\mathrm{~s}, 1 \mathrm{H}), 4.83(\mathrm{~s}, 1 \mathrm{H}), 4.65(\mathrm{~s}, 2 \mathrm{H}), 4.58(\mathrm{~s}, 1 \mathrm{H}), 4.46(\mathrm{t}$, $J=6.1 \mathrm{~Hz}, 2 \mathrm{H}), 4.19(\mathrm{t}, J=6.2 \mathrm{~Hz}, 2 \mathrm{H}), 4.08(\mathrm{~d}, J=5.0 \mathrm{~Hz}, 2 \mathrm{H}), 2.70(\mathrm{t}, J=6.4 \mathrm{~Hz}, 2 \mathrm{H}), 2.58(\mathrm{t}$, $J=6.5 \mathrm{~Hz}, 2 \mathrm{H}), 2.06-1.91(\mathrm{~m}, 4 \mathrm{H}), 1.87-1.81(\mathrm{~m}, 2 \mathrm{H}), 1.71(\mathrm{~s}, 3 \mathrm{H}), 1.68-1.55(\mathrm{~m}, 3 \mathrm{H}), 1.53-$ 1.40 (s, 3H), 1.00 (s, 3H); ${ }^{13} \mathrm{C} \mathrm{NMR}\left(75 \mathrm{MHz}, \mathrm{CDCl}_{3}\right) \delta 172.68,171.46,169.60,158.86,149.84$, $147.69,147.22,138.01,135.55,129.60,128.45,112.22,111.54,110.00,70.91,66.95,63.81,52.56$, $41.61,41.37,39.69,39.63,32.96,30.51,29.26,26.97,25.14,24.89,24.71,16.52$; HRMS (ESI) calculated for $\mathrm{C}_{33} \mathrm{H}_{43} \mathrm{~N}_{3} \mathrm{NaO}_{10} \mathrm{~S}[\mathrm{M}+\mathrm{Na}]^{+} 696.2561$, found 696.2576 .

\subsection{Compound 18b}

Yellowish liquid, yield 53\%. ${ }^{1} \mathrm{H}$ NMR (300 MHz, $\left.\mathrm{CDCl}_{3}\right) \delta 8.14-7.99(\mathrm{~m}, 2 \mathrm{H}), 7.77(\mathrm{t}, J=7.5$ $\mathrm{Hz}, 1 \mathrm{H}), 7.64(\mathrm{t}, J=7.7 \mathrm{~Hz}, 2 \mathrm{H}), 6.24(\mathrm{~s}, 1 \mathrm{H}), 5.81(\mathrm{dd}, J=17.8,10.5 \mathrm{~Hz}, 1 \mathrm{H}), 5.04(\mathrm{~s}, 1 \mathrm{H}), 5.02$ (s, 1H), $4.93(\mathrm{~d}, J=3.1 \mathrm{~Hz}, 1 \mathrm{H}), 4.88(\mathrm{~d}, J=1.4 \mathrm{~Hz}, 1 \mathrm{H}), 4.83(\mathrm{~s}, 1 \mathrm{H}), 4.61(\mathrm{~s}, 2 \mathrm{H}), 4.58(\mathrm{~s}, 1 \mathrm{H})$, $4.46(\mathrm{t}, J=6.2 \mathrm{~Hz}, 2 \mathrm{H}), 4.18(\mathrm{t}, J=6.2 \mathrm{~Hz}, 2 \mathrm{H}), 3.54(\mathrm{dd}, J=11.9,6.0 \mathrm{~Hz}, 2 \mathrm{H}), 2.68(\mathrm{t}, J=6.7 \mathrm{~Hz}$, 2H), $2.59(\mathrm{t}, J=5.9 \mathrm{~Hz}, 2 \mathrm{H}), 2.48(\mathrm{t}, J=6.7 \mathrm{~Hz}, 2 \mathrm{H}), 2.06-1.91(\mathrm{~m}, 4 \mathrm{H}), 1.90-1.78(\mathrm{~m}, 2 \mathrm{H})$, $1.71(\mathrm{~s}, 3 \mathrm{H}), 1.70-1.54(\mathrm{~m}, 3 \mathrm{H}), 1.53-1.40(\mathrm{~m}, 3 \mathrm{H}), 1.01(\mathrm{~s}, 3 \mathrm{H}) ;{ }^{13} \mathrm{C} \mathrm{NMR}\left(75 \mathrm{MHz}, \mathrm{CDCl}_{3}\right) \delta$ $172.33,171.85,170.76,158.43,149.43,147.62,146.85,137.52,135.16,129.20,128.04,111.79$, $110.63,109.60,70.46,65.87,63.32,52.11,41.23,39.26(2), 34.39,33.52,32.51,30.34,28.87,26.52$, 24.72, 24.47, 24.33, 16.07; HRMS (ESI) calculated for $\mathrm{C}_{34} \mathrm{H}_{46} \mathrm{~N}_{3} \mathrm{NaO}_{10} \mathrm{~S}[\mathrm{M}+\mathrm{H}]^{+} 688.2898$, found 688.2908 .

\subsection{Compound 18c}

Yellowish liquid, yield 64\%. ${ }^{1} \mathrm{H} \mathrm{NMR}\left(300 \mathrm{MHz}, \mathrm{CDCl}_{3}\right) \delta 8.06(\mathrm{~d}, J=7.6 \mathrm{~Hz}, 2 \mathrm{H}), 7.76(\mathrm{t}, J=$ $7.4 \mathrm{~Hz}, 1 \mathrm{H}), 7.63(\mathrm{t}, J=7.7 \mathrm{~Hz}, 2 \mathrm{H}), 6.28(\mathrm{~d}, J=6.9 \mathrm{~Hz}, 1 \mathrm{H}), 5.81(\mathrm{dd}, J=17.7,10.6 \mathrm{~Hz}, 1 \mathrm{H}), 5.05$ (s, 1H), $5.02(\mathrm{~s}, 1 \mathrm{H}), 4.93(\mathrm{~d}, J=3.6 \mathrm{~Hz}, 1 \mathrm{H}), 4.88(\mathrm{~s}, 1 \mathrm{H}), 4.82(\mathrm{~s}, 1 \mathrm{H}), 4.70-4.57(\mathrm{~m}, 4 \mathrm{H}), 4.46$ $(\mathrm{t}, J=6.1 \mathrm{~Hz}, 2 \mathrm{H}), 4.19(\mathrm{t}, J=6.0 \mathrm{~Hz}, 2 \mathrm{H}), 2.73-2.63(\mathrm{~m}, 2 \mathrm{H}), 2.55(\mathrm{t}, J=6.5 \mathrm{~Hz}, 2 \mathrm{H}), 2.03-$ $1.93(\mathrm{~m}, 4 \mathrm{H}), 1.86-1.80(\mathrm{~m}, 2 \mathrm{H}), 1.70(\mathrm{~s}, 3 \mathrm{H}), 1.67-1.52(\mathrm{~m}, 3 \mathrm{H}), 1.49-1.41(\mathrm{~m}, 6 \mathrm{H}), 1.00(\mathrm{~s}$, $3 \mathrm{H}) ;{ }^{13} \mathrm{C}$ NMR (75 MHz, $\left.\mathrm{CDCl}_{3}\right) \delta 172.59,172.53,170.85,158.74,149.72,147.67,147.09,137.88$, 135.47, 129.51, 128.31, 112.10, 111.16, 109.88, 70.81, 66.76, 63.67, 52.47, 48.03, 41.55, 39.58, $39.51,32.84,30.47,29.16,26.87,25.01,24.77,24.60,18.15,16.42$; HRMS (ESI) calculated for $\mathrm{C}_{34} \mathrm{H}_{45} \mathrm{~N}_{3} \mathrm{NaO}_{10} \mathrm{~S}[\mathrm{M}+\mathrm{Na}]^{+}$710.2718, found 710.2734.

\subsection{Compound 18d}

Yellowish liquid, yield 67\%. ${ }^{1} \mathrm{H} \mathrm{NMR}\left(300 \mathrm{MHz}, \mathrm{CDCl}_{3}\right) \delta 8.13-7.99(\mathrm{~m}, 2 \mathrm{H}), 7.77(\mathrm{t}, J=7.5$ $\mathrm{Hz}, 1 \mathrm{H}), 7.64(\mathrm{t}, J=7.7 \mathrm{~Hz}, 2 \mathrm{H}), 6.25(\mathrm{~d}, J=8.6 \mathrm{~Hz}, 1 \mathrm{H}), 5.81(\mathrm{dd}, J=17.8,10.5 \mathrm{~Hz}, 1 \mathrm{H}), 5.07(\mathrm{~s}$, $1 \mathrm{H}), 5.03(\mathrm{~s}, 1 \mathrm{H}), 4.93(\mathrm{~d}, J=3.4 \mathrm{~Hz}, 1 \mathrm{H}), 4.88(\mathrm{~d}, J=0.9 \mathrm{~Hz}, 1 \mathrm{H}), 4.83(\mathrm{~s}, 1 \mathrm{H}), 4.72-4.61(\mathrm{~m}$, $3 \mathrm{H}), 4.58(\mathrm{~s}, 1 \mathrm{H}), 4.45(\mathrm{t}, J=6.2 \mathrm{~Hz}, 2 \mathrm{H}), 4.19(\mathrm{t}, J=6.2 \mathrm{~Hz}, 2 \mathrm{H}), 2.81-2.64(\mathrm{~m}, 2 \mathrm{H}), 2.64-2.54$ (m, 2H), $2.11-1.78(\mathrm{~m}, 7 \mathrm{H}), 1.71(\mathrm{~s}, 3 \mathrm{H}), 1.67-1.53(\mathrm{~m}, 3 \mathrm{H}), 1.53-1.37(\mathrm{~m}, 4 \mathrm{H}), 1.28-1.11$ (m, $1 \mathrm{H}), 1.01(\mathrm{~s}, 3 \mathrm{H}), 0.96-0.88(\mathrm{~m}, 6 \mathrm{H}) ;{ }^{13} \mathrm{C} \mathrm{NMR}\left(75 \mathrm{MHz}, \mathrm{CDCl}_{3}\right) \delta 172.31,171.26,170.62$, $158.42,149.43,147.27,146.81,137.51,135.17,129.20,128.03,111.79,111.27,109.60,70.46$, 66.45, 63.37, 56.01, 52.15, 41.00, 39.26(2), 37.51, 32.45, 30.34, 28.90, 26.46, 24.70, 24.57, 24.46, 24.34, 16.06, 14.98, 11.18; HRMS (ESI) calculated for $\mathrm{C}_{37} \mathrm{H}_{52} \mathrm{~N}_{3} \mathrm{O}_{10} \mathrm{~S}[\mathrm{M}+\mathrm{H}]^{+} 730.3368$, found 
730.3371.

\subsection{Compound 18e}

Yellowish liquid, yield 61\%. ${ }^{1} \mathrm{H}$ NMR $\left(300 \mathrm{MHz}, \mathrm{CDCl}_{3}\right) \delta 8.09-7.98(\mathrm{~m}, 2 \mathrm{H}), 7.76(\mathrm{t}, J=7.5$ $\mathrm{Hz}, 1 \mathrm{H}), 7.62$ (t, $J=7.7 \mathrm{~Hz}, 2 \mathrm{H}), 7.35-7.18(\mathrm{~m}, 3 \mathrm{H}), 7.16-7.07(\mathrm{~m}, 2 \mathrm{H}), 6.17(\mathrm{~d}, J=7.7 \mathrm{~Hz}, 1 \mathrm{H})$, $5.81(\mathrm{dd}, J=17.8,10.5 \mathrm{~Hz}, 1 \mathrm{H}), 5.03(\mathrm{~s}, 2 \mathrm{H}), 4.96-4.87(\mathrm{~m}, 3 \mathrm{H}), 4.84(\mathrm{~s}, 1 \mathrm{H}), 4.71-4.52(\mathrm{~m}$, $3 \mathrm{H}), 4.45(\mathrm{t}, J=6.2 \mathrm{~Hz}, 2 \mathrm{H}), 4.17(\mathrm{t}, J=6.2 \mathrm{~Hz}, 2 \mathrm{H}), 3.22-3.06(\mathrm{~m}, 2 \mathrm{H}), 2.70-2.60(\mathrm{~m}, 2 \mathrm{H})$, $2.51(\mathrm{t}, J=6.6 \mathrm{~Hz}, 2 \mathrm{H}), 2.05-1.91(\mathrm{~m}, 4 \mathrm{H}), 1.88-1.72(\mathrm{~m}, 2 \mathrm{H}), 1.71(\mathrm{~s}, 3 \mathrm{H}), 1.69-1.55(\mathrm{~m}, 3 \mathrm{H})$, $1.54-1.39(\mathrm{~m}, 3 \mathrm{H}), 1.00(\mathrm{~s}, 3 \mathrm{H}) ;{ }^{13} \mathrm{C}$ NMR $\left(75 \mathrm{MHz}, \mathrm{CDCl}_{3}\right) \delta 172.21,170.78,170.35,158.43$, $149.44,147.09,146.83,137.53,135.29,135.17,129.21,128.82,128.08,128.04,126.64,111.84$, $111.42,109.62,70.47,66.65,63.38,52.75,52.06,41.02,39.23(2), 37.41,32.47,30.18,28.73,26.47$, 24.71, 24.46, 24.36, 16.07; HRMS (ESI) calculated for $\mathrm{C}_{40} \mathrm{H}_{50} \mathrm{~N}_{3} \mathrm{O}_{10} \mathrm{~S}[\mathrm{M}+\mathrm{H}]^{+}$764.3211, found 764.3207.

\subsection{Compound $18 f$}

Yellowish liquid, yield 45\%. ${ }^{1} \mathrm{H}$ NMR $\left(300 \mathrm{MHz}, \mathrm{CDCl}_{3}\right) \delta 8.06(\mathrm{~d}, J=7.4 \mathrm{~Hz}, 2 \mathrm{H}), 7.76(\mathrm{t}, J=$ $7.2 \mathrm{~Hz}, 1 \mathrm{H}), 7.63(\mathrm{t}, J=7.7 \mathrm{~Hz}, 2 \mathrm{H}), 5.81(\mathrm{dd}, J=17.7,10.5 \mathrm{~Hz}, 1 \mathrm{H}), 5.04(\mathrm{~s}, 1 \mathrm{H}), 4.99(\mathrm{~s}, 1 \mathrm{H})$, $4.92(\mathrm{~d}, J=4.0 \mathrm{~Hz}, 1 \mathrm{H}), 4.88(\mathrm{~s}, 1 \mathrm{H}), 4.82(\mathrm{~s}, 1 \mathrm{H}), 4.69-4.63(\mathrm{~m}, 1 \mathrm{H}), 4.61-4.52(\mathrm{~m}, 3 \mathrm{H}), 4.45$ $(\mathrm{t}, J=6.1 \mathrm{~Hz}, 2 \mathrm{H}), 4.18(\mathrm{t}, J=6.0 \mathrm{~Hz}, 2 \mathrm{H}), 3.68-3.54(\mathrm{~m}, 2 \mathrm{H}), 2.83-2.54(\mathrm{~m}, 4 \mathrm{H}), 2.26-2.14$ (s, $1 \mathrm{H}), 2.07-1.90(\mathrm{~m}, 7 \mathrm{H}), 1.85-1.79(\mathrm{~m}, 2 \mathrm{H}), 1.70(\mathrm{~s}, 3 \mathrm{H}), 1.67-1.53(\mathrm{~m}, 3 \mathrm{H}), 1.52-1.39(\mathrm{~m}$, $3 \mathrm{H}), 1.00(\mathrm{~s}, 3 \mathrm{H}) ;{ }^{13} \mathrm{C} \mathrm{NMR}\left(75 \mathrm{MHz}, \mathrm{CDCl}_{3}\right) \delta 172.85,171.84,169.95,158.82,149.90,148.05$, $147.25,138.03,135.53,129.59,128.41,112.15,110.80,109.90,70.92,66.52,63.60,58.72,52.60$, 46.78, 41.66, 39.71, 39.66, 32.96, 29.13, 29.05, 28.76, 26.99, 25.11, 24.87, 24.66, 24.58, 16.51; HRMS (ESI) calculated for $\mathrm{C}_{36} \mathrm{H}_{47} \mathrm{~N}_{3} \mathrm{NaO}_{10} \mathrm{~S}[\mathrm{M}+\mathrm{Na}]^{+} 736.2874$, found 736.2868.

\subsection{Pharmacology}

\subsubsection{In vitro antiproliferative assay}

SGC-7901, HeLa and U87 cells were purchased from Nanjing Key Gen Biotech Co. Ltd. (Nanjing, China). The cytotoxicity of the compounds was determined using MTT assay. Briefly, test cell lines were plated on 96-well plates at the density of $5 \times 10^{4} /$ well and incubated for $24 \mathrm{~h}$ at $37{ }^{\circ} \mathrm{C}$ under an atomosphere of $5 \% \mathrm{CO}_{2}$. The test compounds were dissolved in the culture medium with $0.5 \%$ DMSO at different concentrations and treated to the cells for another $72 \mathrm{~h}$. The MTT (5 $\mathrm{mg} / \mathrm{mL}$ in PBS) was added and incubated for another $4 \mathrm{~h}$, the optical density was detected with a microplate reader at $490 \mathrm{~nm}$. The $\mathrm{IC}_{50}$ values were calculated according to the dose-dependent curves. All the tests were repeated in at least three independent experiments [38-40].

\subsubsection{Griess assay}

The levels of NO generated by individual compounds in the lysates are presented as that of nitrite. Briefly, a mixture of $100 \mu \mathrm{M}$ test compound and $5.0 \mathrm{mM} \mathrm{L}$-cysteine was incubated at $37{ }^{\circ} \mathrm{C}$ for 120 min, and sampled every $15 \mathrm{~min}$. The collected samples $(2 \mathrm{~mL})$ were mixed with $0.5 \mathrm{~mL}$ of Griess reagent and incubated at $37{ }^{\circ} \mathrm{C}$ for another $15 \mathrm{~min}$, followed to be determined at $540 \mathrm{~nm}$ using a Microplate Reader (Tecan, Männedorf, Switzerland). Each compound was measured in triplicate. Standard sodium nitrite solutions at different concentrations were used to construct the calibration curve, from which the amount of NO release was calculated [35,37].

\subsubsection{Cell cycle analysis}


U87 cells were treated with 11a at concentrations of $0,0.5,1.0$ and $2.0 \mathrm{nM}$ for $72 \mathrm{~h}$, respectively. The cells were trypsinized, washed with PBS and centrifuged. The collected cells were fixed by adding $70 \%$ ethanol at $4{ }^{\circ} \mathrm{C}$ overnight and incubated for $30 \mathrm{~min}$ in PBS containing $100 \mu \mathrm{L}$ RNase A and $400 \mu \mathrm{L}$ of propidium iodide. Analysis of the cell DNA content was performed with the system software (Cell Quest, BD Biosciences, USA) [38-40].

\subsubsection{Cellular apoptosis analysis}

U87 cells were seeded into 6-well plates and incubated at $37^{\circ} \mathrm{C}$ for $24 \mathrm{~h}$, and then treated different concentrations of 11a $(0,0.5,1.0$ and $2.0 \mathrm{nM})$ for another $72 \mathrm{~h}$. Cells were washed twice in PBS and resuspended in $500 \mu \mathrm{L}$ Annexin V binding buffer. Then $5 \mu \mathrm{L}$ Annexin V-APC and $5 \mu \mathrm{L} 7$-AAD were added successively and the mixture was incubated for 15 min under dark conditions at $25^{\circ} \mathrm{C}$. Apoptosis was analyzed using a FACS Calibur flow cytometer (BectoneDickinson, San Jose, CA, USA) [38-40].

\subsubsection{Western blotting analysis}

U87 cells were incubated with 11a at the indicated concentrations for $72 \mathrm{~h}$. The cells were harvested and lysed using lysis buffer, and the solution was centrifuged at 14,000 $\mathrm{g}$ for $10 \mathrm{~min}$ at $4{ }^{\circ} \mathrm{C}$. Then the protein concentrations were determined, and individual cell lysates ( $25 \mu \mathrm{g}$ per lane) were separated by sodium dodecyl sulfate polyacrylamide gel electrophoresis (10\% gel, SDS-PAGE) and transferred onto nitrocellulose membranes. After being blocked with 5\% fat-free milk, the target proteins in the membranes were probed with monoclonal antibodies against p-Akt, Akt, Bcl-2, Bax, caspase-3, pro-caspase-3, GAPDH (KeyGEN Biotech, Nanjing, China) at $4{ }^{\circ} \mathrm{C}$ overnight, respectively. The bound antibodies were detected by horseradish peroxidase (HRP) conjugated second antibodies and visualized using an enhanced chemiluminescent reagent. The relative levels of each signaling event to control GAPDH were determined by densimetric scanning $[20,29,40]$.

\subsubsection{In vivo antitumor assay}

Five-week-old male Institute of Cancer Research (ICR) mice were purchased from Shanghai SLAC Laboratory Animals Co. Ltd. A total of $1 \times 10^{6} \mathrm{H} 22$ cells were subcutaneously inoculated into the right flank of ICR mice according to protocols of tumor transplant research, to initiate tumor growth. Incubated after one day, mice were weighted and at random divided into 4 groups ( 8 mice/group). The groups were treated with $\beta$-elemene $(60 \mathrm{mg} / \mathrm{kg})$ and $11 \mathrm{a}(30,60 \mathrm{mg} / \mathrm{kg})$ in a vehicle of $10 \% \mathrm{DMF} / 2 \%$ Tween $80 / 88 \%$ saline, respectively. Vehicle was used as negative control. Treatments were done at a frequency of intravenous injection one dose per day for three weeks. The mice were sacrificed, and the tumors were excised and weighed. The inhibition rate was calculated as follows: Tumor inhibitory ratio $(\%)=(1$-average tumor weight of treated group/average tumor weight of control group) $\times 100 \%[40,41]$.

\section{Acknowledgments}

This study was financially supported by the National Natural Science Foundation of China (No. 81373280, 81673306), the Project Program of the State Key Laboratory of Natural Medicines, China Pharmaceutical University (No. SKLNMKF201710), and the Innovation project of Jiangsu Province (No. KYLX15_0633).

\section{Appendix A. Supplementary data}

Supplementary data related to this article can be found at 


\section{References}

[1] G.M. Cragg, D.J. Newman, Natural products: A continuing source of novel drug leads, Biochim. Biophys. Acta. 1830 (2013) 3670-3695.

[2] B.B. Mishra, V.K. Tiwari, Natural products: an evolving role in future drug discovery, Eur. J. Med. Chem. 46 (2011) 4769-4807.

[3] D.J. Newman, G.M. Cragg. Natural products as sources of new drugs from 1981 to 2014, J. Nat. Prod. 79 (2016) 629-661.

[4] S.L. Chen, J. You, G.J. Wang, Supercritical fluid extraction of $\beta$-elemene under lower pressure, Se. Pu. 19 (2001) 179-181.

[5] A.F. Barrero, M.M. Herrador, J.F. Quílez del Moral, P. Arteaga, N. Meine, M.C. Pérez-Morales, J.V. Catalán, Efficient synthesis of the anticancer $\beta$-elemene and other bioactive elemanes from sustainable germacrone, Org. Biomol. Chem. 9 (2011) 1118-1125.

[6] Y.Q. Yao, X. Ding, Y.C. Jia, C.X. Huang, Y.Z. Wang, Y.H. Xu, Anti-tumor effect of $\beta$-elemene in glioblastoma cells depends on p38 MAPK activation, Cancer Lett. 264 (2008) 127-134.

[7] F. Bao, J. Qiu, H. Zhang, Potential role of $\beta$-elemene on histone H1 in the H22 ascites hepatoma cell line, Mol. Med. Rep. 6 (2012) 185-190.

[8] C. Guan, W. Liu, Y. Yue, H. Jin, X. Wang, X.J, Wang, Inhibitory effect of $\beta$-elemene on human breast cancer cells, Int. J. Clin. Exp. Pathol. 7 (2014) 3948-3956.

[9] J. Liu, Y. Zhang, J.Y. Qu, L. Xu, K.Z. Hou, J.D. Zhang, X.J. Qu, Y.P. Liu, $\beta$-Elemene-induced autophagy protects human gastric cancer cells from undergoing apoptosis. BMC cancer 11 (2011) 183-192.

[10] X.X. Peng, Y.L. Zhao, X.Y. Liang, L.J. Wu, S.Q. Cui, H.Q. Ai, M. Guo, W. Wang, Assessing the quality of RCTs on the effect of $\beta$-elemene, one ingredient of a Chinese herb, against malignant tumors, Contemp. Clin. Trials 27 (2006) 70-82.

[11] L.Y. Xu, S.J. Tao, X.M. Wang, Z.Y. Yu, M.W. Wang, D. Chen, Y.G. Jing, J.H. Dong, The synthesis and anti-proliferative effects of $\beta$-elemene derivatives with mTOR inhibition activity, Bioorg. Med. Chem. 14 (2006) 5351-5356.

[12] Y. Dong, L. Li, L. Wang, T. Zhou, J.W. Liu, Y.J. Gao, Preliminary study of the effects of $\beta$ elemene on MCF-7/ADM breast cancer stem cells, Genet. Mol. Res. 14 (2015) 2347-2355.

[13] D. Fukumura, S. Kashiwagi, R.K. Jain, The role of nitric oxide in tumour progression, Nature Rev. Cancer 6 (2006), 521-534.

[14] B. Bonavida, S. Baritaki, S. Huerta-Yepez, M. I. Vega, D. Chatterjee, K. Yeung, Novel therapeutic applications of nitric oxide donors in cancer: roles in chemo- and immunosensitization to apoptosis and inhibition of metastases, Nitric Oxide 19 (2008) 152-157.

[15] D. Hirst, T. Robson, Nitric oxide in cancer therapeutics: Interaction with cytotoxic chemotherapy, Curr. Pharm. Des. 16 (2010) 411-420.

[16] S. Ning, M. Bednarski, B. Oronsky, J. Scicinski, S. J. Knox, Novel nitric oxide generating compound glycidyl nitrate enhances the therapeutic efficacy of chemotherapy and radiotherapy, Biochem. Biophys. Res. Commun. 447 (2014) 537-542.

[17] Q.A. Jia, A.J. Janczuk, T.W. Cai, M. Xian, Z. Wen, P.G. Wang, NO donors with anticancer activity, Expert Opin. Ther. Pat. 12 (2002) 819-826.

[18] G. Aguirre, M. Boiani, H. Cerecetto, M. Fernandez, M. Gonzalez, E. Leon, C. Pintos, S. Raymondo, C. Arredondo, J.P. Pacheco, M.A. Basombrio, Furoxan derivatives as cytotoxic agents: 
preliminary in vivo antitumoral activity studies, Pharmazie 61 (2006) 54-59.

[19] M.A.E. Mourad, M. Abdel-Aziz, G.E.D.A.A. Abuo-Rahma, H.H. Farag, Design, synthesis and anticancer activity of nitric oxide donating/chalcone hybrids, Eur. J. Med. Chem. 54 (2012) 907913.

[20] Y. Ai, F.H. Kang, Z.J. Huang, X.W. Xue, Y.S. Lai, S.X. Peng, J.D. Tian, Y.H. Zhang, Synthesis of CDDO-amino acid-nitric oxide donor trihybrids as potential antitumor agents against both drugsensitive and drug-resistant colon cancer, J. Med. Chem. 58 (2015) 2452-2464.

[21] N. Zhao, K.T. Tian, K.G. Cheng, T. Han, X. Hu, D.H. Li, Z.L. Li, H.M. Hua, Antiproliferative activity and apoptosis inducing effects of nitric oxide donating derivatives of evodiamine, Bioorg. Med. Chem. 24 (2016) 2971-2978.

[22] D.H. Li, T. Han, K.G. Tian, S. Tang, S.T. Xu, X. Hu, L. Wang, Z.L. Li, H.M. Hua, J.Y. Xu, Novel nitric oxide-releasing spirolactone-type diterpenoid derivatives with in vitro synergistic anticancer activity as apoptosis inducer, Bioorg. Med. Chem. Lett. 26 (2016) 4191-4196.

[23] C.P. Landowski, B.S. Vig, X.Q. Song, G.L. Amidon, Targeted delivery to PEPT1overexpressing cells: acidic, basic, and secondary floxuridine amino acid ester prodrugs, Mol. Cancer Ther. 4 (2005) 659-667.

[24] X. Song, P.L. Lorenzi, C.P. Landowski, B.S. Vig, J.M. Hilfinger, G.L. Amidon, Amino acid ester prodrugs of the anticancer agent gemcitabine: synthesis, bioconversion, metabolic bioevasion, and hPEPT1-mediated transport, Mol. Pharmaceutics 2 (2005) 157-167.

[25] F. Cao, J.H. Jia, Z. Yin, Y.H. Gao, L. Sha, Y.S. Lai, Q.N. Ping, Y.H. Zhang, Ethylene glycollinked amino acid diester prodrugs of oleanolic acid for PepT1-mediated transport: synthesis, intestinal permeability and pharmacokinetics, Mol. Pharm. 9 (2012) 2127-2135.

[26] L. Fang, M. Wang, S. Gou, X. Liu, H .Zhang, F. Gao, Combination of amino acid/dipeptide with nitric oxide donating oleanolic acid derivatives as PepT1 targeting antitumor prodrugs, J. Med, Chem. 57 (2014) 1116-1120

[27] D.P. Brazil, J. Park, B.A. Hemmings, PKB binding proteins: Getting in on the Akt, Cell 111 (2002) 293-303.

[28] G. Dufour, M.J. Demers, D. Gagné, A.B. Dydensborg, I.C. Teller, V. Bouchard, I. Degongre, J.F. Beaulieu, J.Q. Cheng, N. Fujita, T. Tsuruo, K. Vallée, P.H. Vachon, Human intestinal epithelial cell survival and anoikis differentiation state-distinct regulation and roles of protein kinase B/Akt isoforms, J. Biol. Chem. 279 (2004) 44113-44122.

[29] Z.T. Zhu, H.Z. Sun, G.Y. Ma, Z.H. Wang, E.Z. Li, Y.Y. Liu, Y.P. Liu, Bufalin induces lung cancer cell apoptosis via the inhibition of PI3K/Akt pathway, Int. J. Mol. Sci. 13 (2012) 20252035.

[30] Y. Tian, Y. Nan, L. Han, A.L. Zhang, G.X. Wang, Z.F. Jia, J.W. Jiang, P.Y. Pu, Y. Zhong, C.S. Kang, MicroRNA miR-451 downregulates the PI3K/AKT pathway through CAB39 in human glioma, Int. J. Oncol. 40 (2012) 1105-1112.

[31] Y.H. Zhan, J. Liu, X.J. Qu, K.Z. Hou, K.F. Wang, Y.P. Liu, B. Wu, $\beta$-Elemene induces apoptosis in human renal-cell carcinoma 786-0 cells through inhibition of MAPK/ERK and PI3K/Akt/mTOR signaling pathways, Asian Pac. J. Cancer Prev. 13 (2012) 2739-2744.

[32] H. Huang, J.C. Cheville, Y. Pan, P.C. Roche, L.J. Schmidt, D.J. Tindall, PTEN induces chemosensitivity in PTEN mutated prostate cancer cells by suppression of Bcl-2 expression, J. Biol. Chem. 276 (2001) 38830-38836. 
[33] N. Festjens, M. van Gurp, G. van Loo, X. Saelens, P. Vandenabeele, Bcl-2 family members as sentinels of cellular integrity and role of mitochondrial intermembrane space proteins in apoptotic cell death, Acta Haematol. 111 (2004) 7-27.

[34] N.A. Thornberry, Y. Lazebnik, Caspases: enemies within, Science 281 (1998) 1312-1316.

[35] D.H. Li, L. Wang, H. Cai, Y.H. Zhang, J.Y. Xu, Synthesis and biological evaluation of novel furozan-based nitric oxide-releasing derivatives of oridonin as potential anti-tumor agents, Molecules 17 (2012) 7556-7568.

[36] J.C. Chen, W.L. Duan, R.R. Bai, H.Q. Yao, J. Shang, J.Y. Xu, Design, synthesis and antioxidant activity evaluation of novel $\beta$-elemene derivatives, Bioorg. Med. Chem. Lett. 24 (2014) 3407-3411. [37] R.R. Bai, X. Yang, Y. Zhu, Z.W. Zhou, W.J. Xie, H.Q. Yao, J.Y. Jiang, J. Liu, M.Q. Shen, X.M. $\mathrm{Wu}$, J.Y. Xu, Novel nitric oxide-releasing isochroman-4-one derivatives: Synthesis and evaluation of antihypertensive activity, Bioorg. Med. Chem. 20 (2012) 6848-6855.

[38] J.F Li, R.Z. Huang, G.Y. Yao, M.Y. Ye, H.S. Wang, Y.M. Pan, J.T. Xiao, Synthesis and biological evaluation of novel aniline-derived asiatic acid derivatives as potential anticancer agents, Eur. J. Med. Chem. 86 (2014) 175-188.

[39] H. Cai, X.J. Huang, S.T. Xu, H. Shen, P.F. Zhang, Y. Huang, J.Y. Jiang, Y.J. Sun, B. Jiang, X.M. Wu, H.Q. Yao, J.Y. Xu, Discovery of novel hybrids of diaryl-1,2,4-triazoles and caffeic acid as dual inhibitors of cyclooxygenase-2 and 5-lipoxygenase for cancer therapy, Eur. J. Med. Chem. 108 (2016) 89-103.

[40] S.T. Xu, H. Yao, S.S. Luo, Y.K. Zhang, D.H. Yang, D.H. Li, T.Y. Wang, M. Hu, Y.Y. Qiu, X.M. Wu, H.Q. Yao, W.J. Xie, Z.S. Chen, J.Y. Xu, A novel potent anticancer compound optimized from a natural oridonin scaffold induces apoptosis and cell cycle arrest through the mitochondrial pathway, J. Med. Chem. 60 (2017) 1449-1468.

[41] B.X. Shi, R.H. Cao, W.X. Fan, L. Guo, Q. Ma, X.M. Chen, G.X. Zhang, L.Q. Qiu, H.C. Song, Design, synthesis and in vitro and in vivo antitumor activities of novel bivalent $\beta$-carbolines, Eur. J. Med. Chem. 60 (2013) 10-22. 